



$$
10228
$$





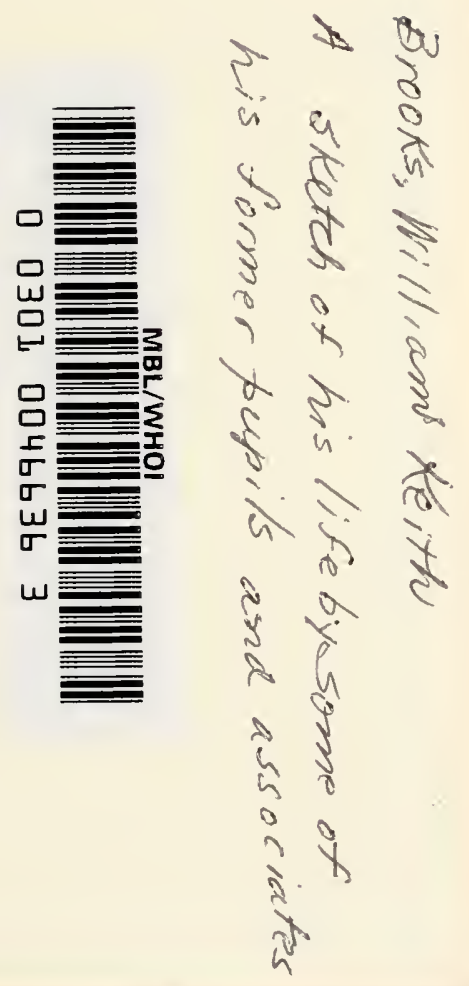




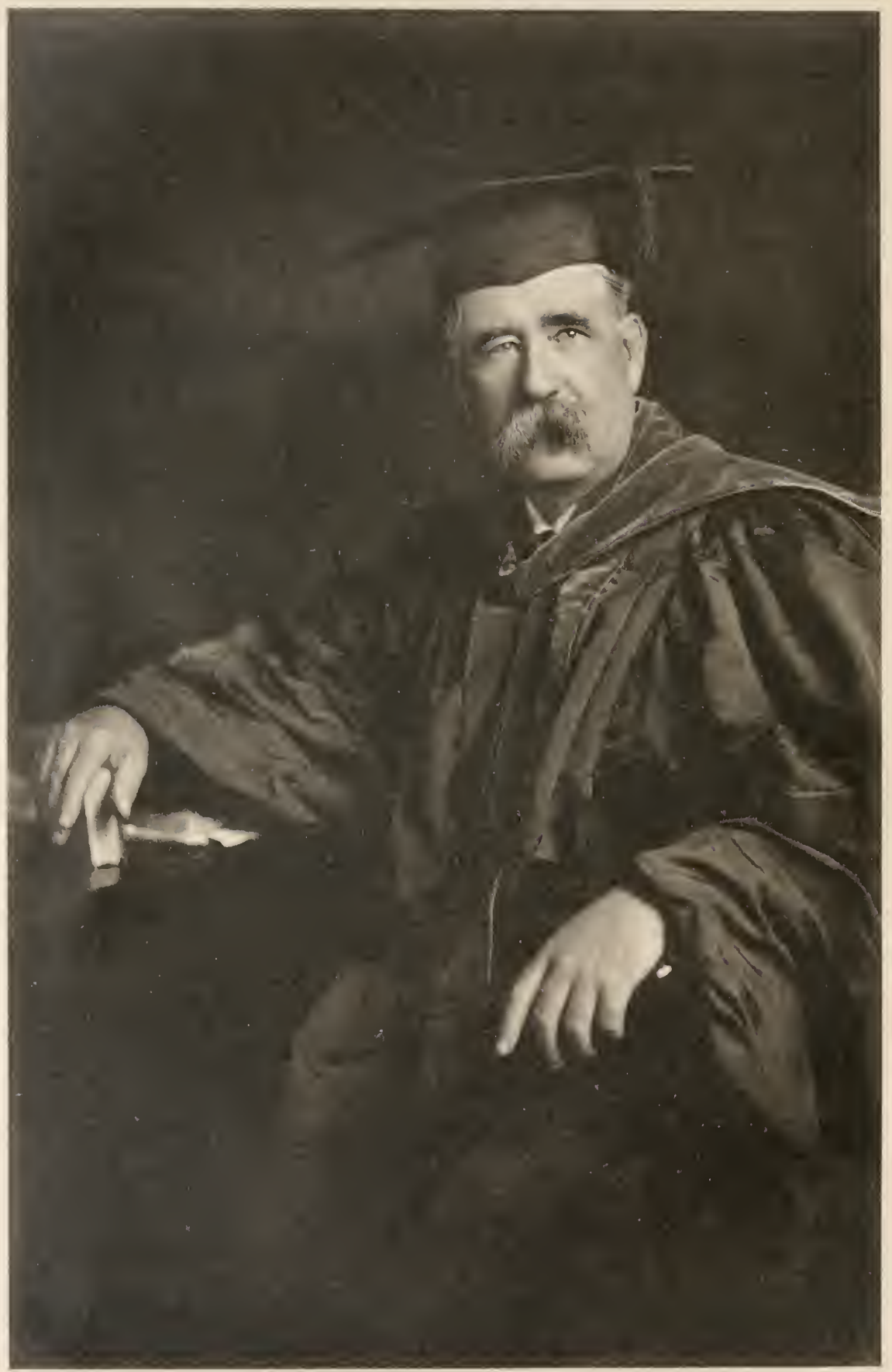




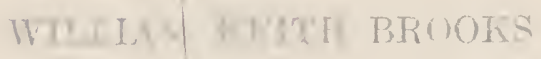

A SEF.MP OF HE Wh if 100

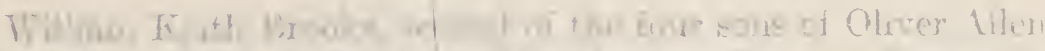

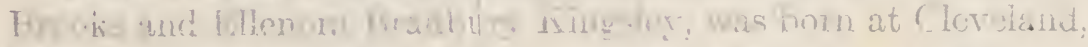

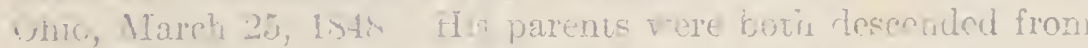
thr evily sethors of Mlassacl wetta, the first of the name having

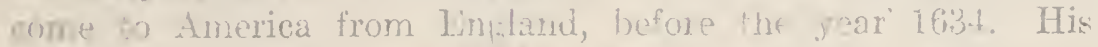

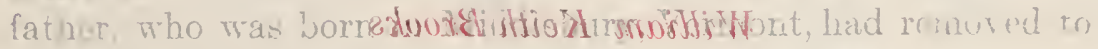

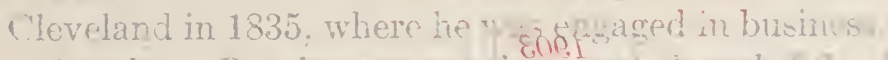

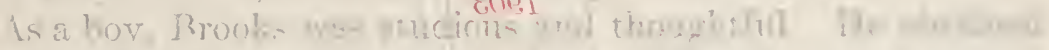

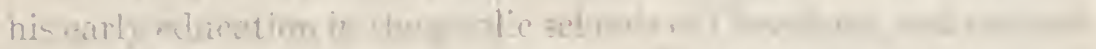

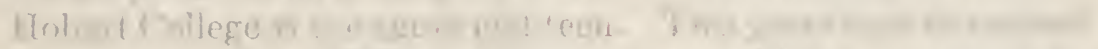

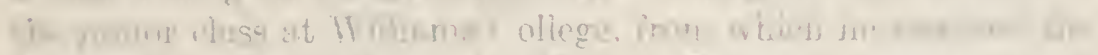

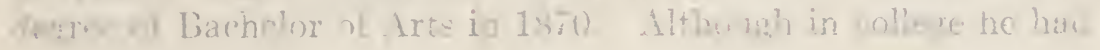

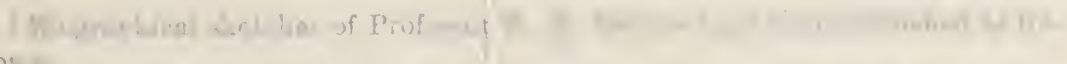
7ns:

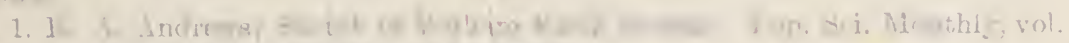

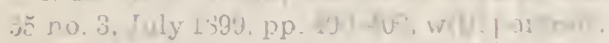

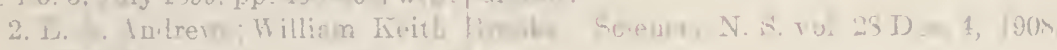

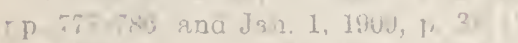

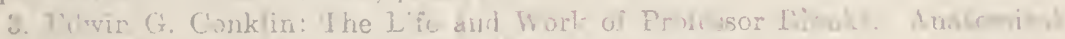

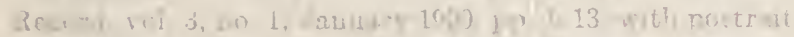

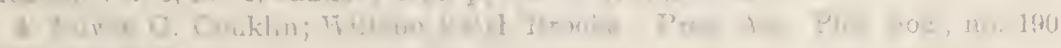
n $1, \ldots 7$

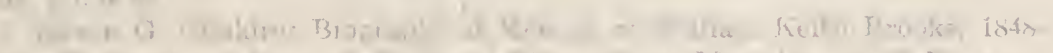

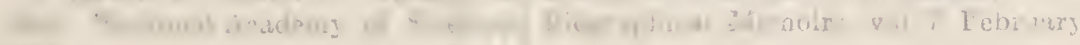
$x^{n+1,1}$

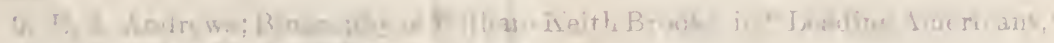
An! del, Nee Yos: 10 !

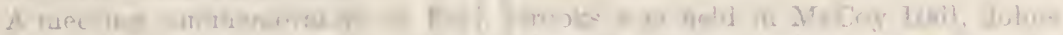

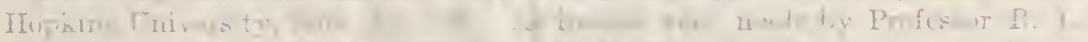

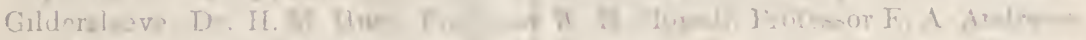

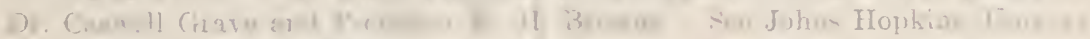

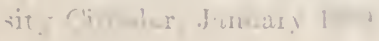




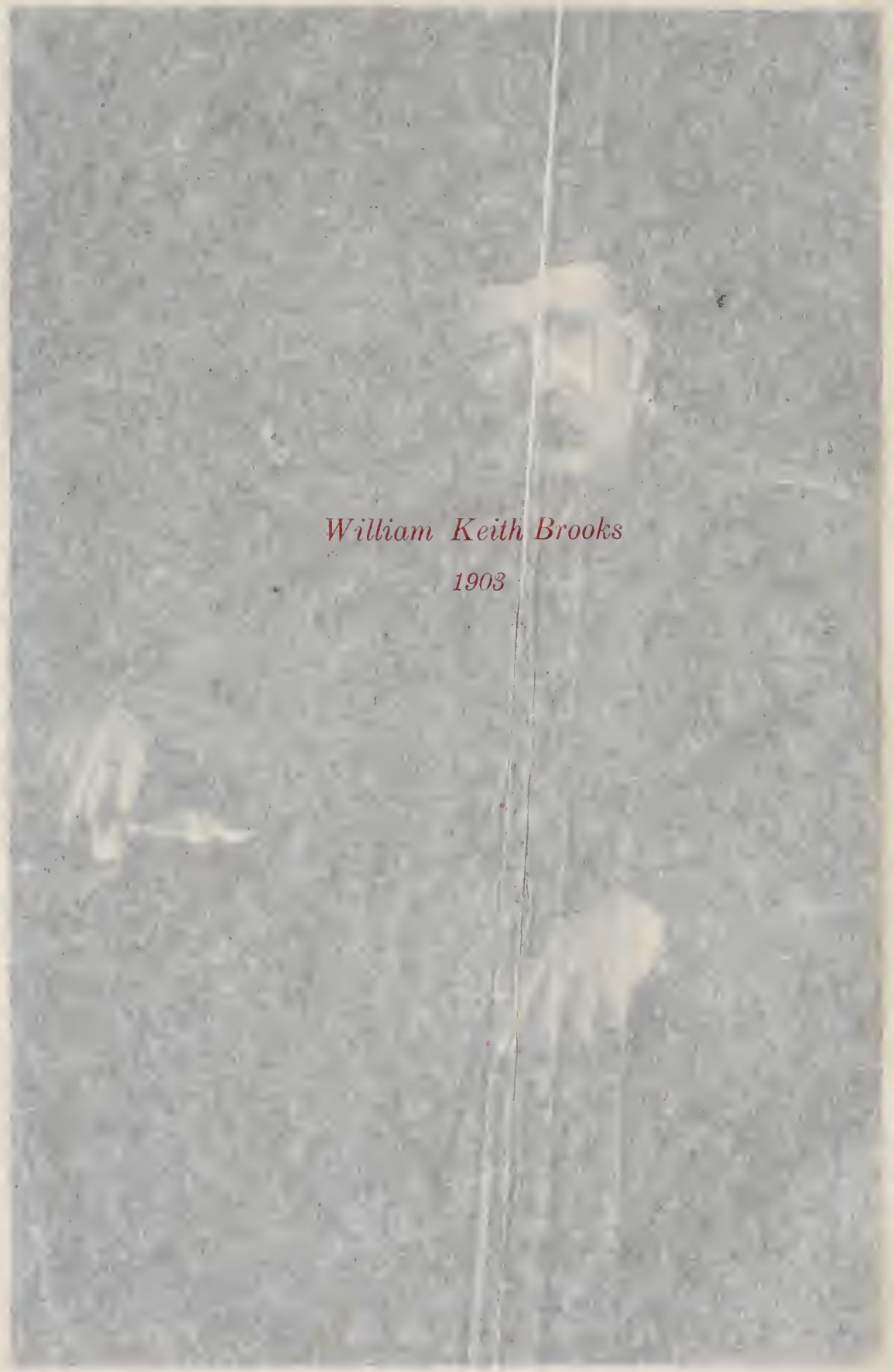




\section{WILLIAM KEITH BROOKS}

\section{A SKETCH OF HIS LIFE BY SOME OF HIS FORMER PUPILS} AND ASSOCIATES ${ }^{1}$

William Keith Brooks, second of the four sons of Oliver Allen Brooks and Ellenora Bradbury Kingsley, was born at Cleveland, Ohio, March 25, 1848. His parents were both descended from the early settlers of Massachusetts, the first of the name having come to America from England, before the year 1634. His father, who was born in Middlebury, Vermont, had removed to Cleveland in 1835, where he was engaged in business.

As a boy, Brooks was studious and thoughtful. He obtained his early education in the public schools of Cleveland, and entered Hobart College at the age of eighteen. Two years later he entered the junior class at Williams College, from which he received the degree of Bachelor of Arts in 1870. Although in college he had

${ }_{1}^{1}$ Biographical sketches of Professor W. K. Brooks have been published as follows:

1. E. A. Andrews; Sketch of William Keith Brooks. Pop. Sci. Monthly, vol. 55 no. 3 , July 1899 , pp. 400-409, with portrait.

2. E. A. Andrews; William Keith Brooks. Science, N. S. vol. 28 Dec. 4, 1908, pp. 777-786, and Jan. 1, 1909, p. 31.

3. Edwin G. Conklin; The Life and Work of Professor Brooks. Anatomical Record, vol. 3, no. 1, January 1909, pp. 1-13, with portrait.

4. Edwin G. Conklin; William Keith Brooks. Proc. Am. Phil. Soc., no. 190, 1909, pp. 3-10.

5. Edwin G. Conklin; Biographical Memoir of William Keith Brooks, 1848 1908. National Academy of Sciences, Biographical Memoirs, vol. 7, February 1910.

6. E. A. Andrews; Biography of William Keith Brooks, in "Leading Americans," Holt \& Co., New York. 1910.

A meeting commemorative of Prof. Brooks was held in McCoy Hall, Johns Hopkins University, Nov. 12, 1908. Addresses were made by Professor B. L. Gildersleeve, Dr. H. M. Hurd, Professor W. H. Howell, Professor E. A. Andrews, Dr. Caswell Grave and Professor W. H. Browne. See Johns Hopkins University Circular, January 1909. 
shown special interest in philosophy and in studies with the microscope, he was uncertain on graduation whether to devote himself to natural history, to mathematics or to Greek, in all of which subjects he excelled. After leaving Williams College he spent a short time with his father in business, but this occupation was not to his liking and he gave it up to become a teacher in a school for boys at Niagara Falls. After holding that position for two years he became a graduate student at Harvard College under Louis Agassiz, who was then at the zenith of his career, and at the seaside laboratory established by this great master in 1873 on the Island of Penikese, Brooks began a life-long devotion to the study of marine zoölogy. In 1875 he was appointed assistant in the museum of the Boston Society of Natural History and in the same year received the degree of Doctor of Philosophy from Harvard. It was during the summer of this year, while at home on his vacation, that he organized, together with Theodore B. Comstock and Albert H. Tuttle, a class for laboratory instruction in zoölogy and botany for teacher's.

With the opening of the Johns Hopkins University in 1876, one of the twenty fellowships was awarded Brooks, who thus at its very foundation entered the service of the institution with which he was to remain connected until his death. He was immediately advanced to the position of Associate and later was successively appointed Associate Professor of Comparative Anatomy, Associate Professor of Morphology, Professor of Animal Morphology, Professor of Zoölogy and Head of the Biological Department. In 1878 he was made Director of the Chesapeake Zoölogical Laboratory of the University, an institution which he organized and which became a potent adjunct to the Baltimore laboratory in the training of biologists.

Professor Brooks was the recipient of numerous public honors. When but thirty-six years of age he was elected a member of the National Academy. He was chosen a member of the American Philosophical Society in 1886, and of the Academy of Natural Sciences in 1887. He was Lowell lecturer in 1901 and gave one of the three general addresses before the International Zoölogical Congress at Boston, in 1907. He received the honorary de- 
gree of LL.D. from Williams College in 1893, from Hobart College in 1899, and from the University of Pennsylvania in 1906. For his discoveries on the life history of the American oyster he was awarded the medal of the Sociéte d'Acclimatation of Paris, and for his work on the Stomatopoda, a Challenger medal. He was editor of the "Memoirs from the Biological Laboratory" of the Johns Hopkins University, joint editor of the "Studies from the Biological Laboratory" of the Johns Hopkins University, and one of the editors of the Journal of Experimental Zoölogy. He was a member of the Boston Society of Natural History, the American Academy of Arts and Sciences, the American Society of Zoölogists, and of the Maryland Academy of Sciences, and was a Fellow of the American Association for the Advancement of Science and of the Royal Microscopical Society.

On June 13, 1878, Professor Brooks married Amelia Katherine schultz (deceased 1901), daughter of Edward Thomas Schultz, and Susan Rebecca (Martin) Schultz of Baltimore. Two children were born, Charles Edward Brooks and Mrs. Menetta White (Brooks) Daniel, both of whom survive him.

A congenital defect of the heart had always caused Professor Brooks to lead a less active life physically than do most men, and to this trouble other bodily ills were added as life advanced. After a continuous prostrating illness of nine months he died at his home "Brightside," near Baltimore, November 12, 1908.

Is a stimulating teacher, an ardent and successful investigator, and a philosophic naturalist, the influence of Brooks on the development of zoölogy in this country has been very great. His students are scattered widely in college and university, in museums, and scientific stations in this country and abroad, and many have become eminent in their own fields of work. His discoveries, numerous and important, have enriched zoölogy and have been incorporated into the permanent literature of that science. Certain of his memoirs are models of completeness and beauty. His brilliant and thorough work on the oyster fisheries of Maryland has made his name familiar to economists and to intelligent legislators. In an age perhaps over-eager in the pursuit of new knowledge Brooks has called attention back to the fundamental 
nature of knowledge itself in such a way that his helpfulness has been gladly and gratefully recognized in many circles of science.

In his personal character Brooks combined gentleness and strength and a rare wisdom. In university matters and in all the affairs of life he was a lover of freedom and of justice tempered with kindliness. Although looked upon from the beginning as a master mind, he was totally free from formality and never ass amed the authoritative air of the traditional professor, but met his students and associates in all simplicity and frankness as fellow student and inquirer. What he was as man and a student was fully revealed, and the singularly deep influence which he exerted upon those who worked with him constitutes a remarkable tribute to his genuine ability and worth. The close friendship between him and his students was evidenced in many ways in the daily life of the laboratory, and at the evening gatherings at his home. It was given more definite expression on the occasion of his promotion to a full professorship, and again on his fiftieth birthday, when his pupils came together at Brightside to present to him formally the portrait for which he had sat at their request.

The appreciations, reviews and recollections embodied in the following pages and coming from former students and associates record some of the labors and some of the traits, human and professional, of a profound thinker and tireless worker.

SOME RECOLLECTIONS OF PROFESSOR BROOKS CHRONOLOG-

ICALLY ARRANGED

1876-79.2 Among the company of twenty young men who came together in Baltimore in 1876 as the first group of "Fellows" of Johns Hopkins University, were three biologists. One of these was of less than average stature, wearing a serious face, with close-set eyes, quiet and unhurried in his movements, speaking not frequently, and never with haste. This was W. K. Brooks of Williams and Harvard. The biological department was at once organized by Professor Martin with Dr. Brooks as an Asso-

2 I'rofessor S. F. Clarke, Williams College. 
ciate, and it is an illustration of that quiet impressiveness of Brooks' simple manner that his appointment was immediately recognized by every one to be most eminently fitting.

He quickly gained our respect and admiration by the constant seriousness of his thoughts, and the simplicity and genuineness of his statements : simple in expression but showing careful and deep reflection. Our affection was won and held by his genuine, never-failing interest in, and friendship for us.

As I recall his reading to me of the then unfinished manuscript of his book on Heredity in my room on Centre street in 1876, of the many long talks on biological subjects, in either his room or mine at the University, at Brightside, or at Crisfield, Fort Wool or Beaufort, I become aware again of the constant seriousness, and power of his thought, which awoke and continually increased an admiration for his intellectual ability.

Brooks' friendship was even and steadfast. It never found great expression in words, but it never wavered. I felt this during my early years of association with him, and the conviction was but strengthened with the growing years. This steadfastness of affection and confidence in his friends, his perfect simplicity and genuineness, and his serious and profound mind are to me the sources of Brooks' great and lasting influence on men.

1883-84. ${ }^{3}$ 'The first time I saw Professor Brooks was in 1883. The year before, while I was endeavoring to make out some of the points in the structure of Balanoglossus, then imperfectly known, it was announced in the Johns Hopkins Circular that a littoral species of that animal had been found at Hampton, Va. At Mr. Adam Sedgwick's suggestion I wrote to Brooks asking if I might come over to investigate it. Brooks, as his friends will remember, did not habitually answer letters, but as it happened he did answer that one and sent me a cordial invitation to come and try. Such leave was no little thing to give, for Balanoglossus must have been known to be one of the prizes of the station, but in professional generosity Brooks was royal and lavish.

3 Professor William Bateson, Cambridge, England. 
From the first moment of meeting in the empty warehouse of the Normal College, which then served for a laboratory, we became friends. He was of course much my senior, but there is no other word which so well expresses the happy unconstrained feeling that I felt towards him and that he showed towards me. It had been settled that I was to live at Mr. Cock's boarding house, across the creek, where the Brooks family had their quarters, and we thus spent several weeks in constant intimacy.

He was not the least like any one else I had ever known, and I find it difficult to express the charm which his personality had for me then, and has had increasingly since. He was, as I soon found, on account of superficial eccentricities reputed a reserved and rather inaccessible man. In general company he would indeed often remain silent and I think he had moods in which a morbid shyness would take complete possession of him, but once at his ease he was another man. At such times he would talk abundantly, but his speech was always that of the taciturnobserver. with the special, holding quality that the speech of such men has. He spoke in short incisive phrases, full of novelty, suggestion, and humorously inventive thought, sometimes, but not often, rising to enthusiasm. I see him now, with his short, round figure, sitting on the piazza at Mr. Cock's or lying flat on his beda posture he often took when in a talking mood-ruminating his thoughts, which, if the truth must be told, were periodically interrupted by his devotion to tobacco. What a strange combination it was! The grave, kindly face, the earnest solemnity of philosophical speculation and the homely quid. Now, I suppose. no university professor, however contemplative, dare use tobaceo in this particular way; but I wonder if any university professor ruminates spacious ideas as Brooks used to do, daily through long vacant hours of leisure, to the delight and elevation of a youthful listener. Those are the times of true education

\section{"when lofty thought}

Lifts the young heart above its mortal lair."

Many of Brooks' pupils must look back on similar pleasant hours of intimate, informal summer laboratory life as critical moments in their development. For myself I know that it was 
through Brooks that I first came to realize the problem which for years has been my chief interest and concern. At Cambridge in the eighties morphology held us like a spell. That part of biology was concrete. The discovery of definite, incontrovertible fact is the best kind of scientific work, and morphological research was still bringing up new facts in quantity. It scarcely occurred to us that the supply of that particular class of fact was exhaustible, still less that facts of other classes might have a wider significance. In 1883 Brooks was just finishing his book "Heredity", and naturally his talk used to turn largely on this subject. He used especially to recur to his ideas on the nature and causes of variation, and to the conception which he developed in "Heredity," that the functions of the male and female germ cells are distinct. The leading thought was that which he expresses in his book (p. 312) that "the obscurity and complexity of the phenomena of heredity afford no ground for the belief that the subject is outside the legitimate province of scientific enquiry." $\mathrm{He}$ deplored the fact that he had no opportunity for the requisite experiments in breeding, but he saw plainly that such experiments were the first necessity for progress in biology.

To me the whole province was new. Variation and heredity with us had stood as axioms. For Brooks they were problems. As he talked of them the insistence of these problems became imminent and oppressive. It all sounded rather inchoate and vaporous at first, intangible as compared with the facts of development which we knew well how to pursue, but with the lapse of time the impression became strong that Brooks was on the right line. That autumn I went home feeling that though in technique we were a long way ahead of Johns Hopkins-I had the pleasure of showing off the Jung microtome, then the latest thing in progress, to the admiring Baltimore men--yet somehow Brooks had access to novelties of a more serious description.

In the following summer I was again with Brooks at Beaufort, N. C., but in that year I soon fell ill and was for a long time too weak for much talk of any kind. Indeed, but for the devoted ministrations of Brooks and his students, who for weeks performed for me the offices of the trained nurse, I might never have left 
Beaufort alive. The "Heredity" had meanwhile appeared and I am afraid Brooks was disappointed with the reception it met, for it was noticed with little more than formal sympathy. Looked at in the light of subsequent knowledge its purpose was indeed rather, as he says, "to turn the attention of others into this channel" than to make an independent advance. In the preface he wrote: "I have little hope that my views will be accepted in the form in which they are here presented, but I do hope that they may serve to bind together and to vitalize the mass of facts which we already possess and that they may thus incite and direct new experiments." That function he and his book did at length admirably perform for many, both in England and in America.

1885-89.4 In going over my memories of Dr. Brooks I find that my mind does not separate him from his environment. I continually see him in the semicommunal life of the laboratory, whether in Baltimore or Beaufort, Woods Hole or the islands of the West Indian sea, which so stirred and charmed him. Even his home life with its restful, satisfying beauty was but a detached fragment of the other larger existence. I think of him as the central figure, wise and kind, of a circle of young men coming from many quarters, from New England, the Middle States, the West, and the South, from Canada, England and Japan, a society from which older member's were always going out to honorable careers and into which new were coming to learn the ways and traditions of the school. Very different were we, but knit together from the start by the strong bond of a common interest, and presently by growing appreciation of him who made the school. It took us but a short time to learn that here was no mere work-shop, well organized and in which we might acquire the requisite degree of skill in a profession, but that we were in the company of a master mind, wide ranging in the fields of knowledge and inquiry, profound in contemplative thought, and with the acuteness of the observer who discovers what has been hidden.

As I dwell on the man and try to single out mental habits and

4 Professor H. V. Wilson, University of North Carolina. 
attributes from the whole of his personality, I come to many that arrest and enchain my attention.

It is interesting to consider his practice and advice to beginners in the study of Nature. It was to start out, not from a general principle, but from some phenomenon that had caught the eye and become a nucleus for thought. Continued, persistent observation and reflection circling round such a center would yield, he held, solid results in the shape of new facts and would sooner or later lead one into living contact with great questions. This method of work was eminently characteristic of his independent, individualistic temperament.

The serenity of Dr. Brooks impressed every one. In a mind so strong, active, and keen, calm temperateness was doubly noticeable. This peace of mind must have been due in part to the fact that his critical insight was unobscured by self-seeking. A firm gaze fixed on the distant goal held the immediately advantageous in its proper place, and gave him a confidence, a quiet boldness that we all recognized.

Brooks frequently said that he tried always to be a reasonable man. And in dealing with men and their ways I am convinced that reasoning did guide him in remarkable degree. His logical habit of thought came in; however, for more congenial exercise in professional work. Do we not all remember the pleasure he had in the skillful disengagement of the idea from the mass of details, and in its portrayal, language and drawing mutually contributing to clearness?

I recall also his strong and helpful faith in the value of labor spent in searching out the order of the universe, the way things happen in nature. For, as he often said, such knowledge both makes the conscious life of man fuller and nobler, and is the basis on which rests all our control of natural phenomena.

The machinery of Professor Brooks' department, the lectures, set tasks and routine, was simple. Experience has shown, however, that it was not inadequate, on the contrary, that it was well adapted to the purpose in view. Brooks' underlying assumptions were that graduate students had come to stay some time, would work as hard as they could, and that they had enough independence 
of mind and enough elementary training to handle books and journals which record the actual state and progress of zoölogy. Of lectures there was one now and then from Professor Brooks on any subject. A round of lectures by older students in the department was given some years, and this was excellent practice.

The journal club was serious. It met weekly and the arrangement was such that each graduate student reported a number of times during the year. A reading club met weekly in the evening at Professor Brooks' house. Some pleasant book of general zoölogical interest, often one of travel, was read, after which came tea. In the laboratory again once a week readings of a more serious nature and with some discussion were held. The "Origin of Species" was in this way gone through, and "Agassiz's Essay on Classification."

Professor Brooks had compiled an elaborate list of the literature, with which it was supposed candidates for the doctor's degree were to make themselves familiar. It included the text-books of the period and important memoirs on the various subdivisions of zoölogy. The list was long. Perhaps some students completed it. But we all read with considerable diligence and it was the custom to make careful abstracts. On the basis of this common reading a good deal of informal talk and discussion was maintained among us.

We lived in the laboratory all day and the younger men learned much from the older, especially in matters of technique. Brooks gave excellent suggestions on drawing and would occasionally go through the form of taking a micro-photograph. A beginner in my time was usually given some material, referred to a paper or two on comparative anatomy or embryology, and told to verify the research. At intervals, frequent enough, Brooks looked at his figures, notes, and preparations and had something to say about the matter. Frequently before this first testing and forming exercise was completed, the man would be put at another. Two or three filled the year. Then came a long season at the seaside laboratory, in all probability the first for the student and teeming with experience. There was daily collecting, much study of live animals, much rearing of embryos and larva. The pelagic 
fauna got in the tow net or at times by dipping came in for a good deal of attention. Numerous quick dissections were made, and quantities of notes and drawings. Brooks exercised little or no supervision over such work, but the older men were a great help to the younger. 'The larger manuals such as Balfour's Embryology, and later Korschelt and Heider, were fairly thumbed. The industry and "go" of Brooks' summer laboratories was remarkable, the lamps lit in the evening, and someone frequently sitting up all through the night to "follow a development." Toward the end of the season, when a little perspective had been acquired and mere mass and variety began to pall, a special form or two was singled out as promising something in the way of new results, and the path of research was thus opened up. The material so collected was studied in detail during the following winter. More intensive reading bearing on the problems as they became defined was undertaken. Informal, short, but helpful talks about the work were had with Brooks from time to time. He would examine particular preparations, quickly to be sure, or would criticise figures. There was never any leading or "nursing" on his part. By the end of the year, though, some grasp of the methods of research had been acquired, and the following summer at the seaside usually found the student able to pursue the line of inquiry on which he had already started, or to strike off into an associated field.

1887-96. ${ }^{5}$ No account of Professor Brooks should omit mention of his love for plants. It is true that this interest was apparently, to a large extent, of secondary influence as far as his published work was concerned but it was very real and occupied a constant place in his thoughts on the broader problems of nature. The relations of the living organism to the environment were well exemplified for him in the plant world. He always kept at hand something of botanical interest, and would invite you into his little greenhouse, or into his garden, to exhibit with pride some product of his own skill. Nowhere, perhaps, was his innate sympathy for

\footnotetext{
${ }^{5}$ Professor Henry McE. Knower, University of Cincinnati.
} 
nature more clearly shown than here. His knowledge of botany was also constantly drawn upon whenever he dwelt on problems of heredity, variation, adaptation, etc.

Brooks' affection for nature was also expressed in his observations on the common domestic animals about him. The exact nature of this interest was unique to my experience, until I heard him read aloud from the pages of Gilbert White. Then I realized how the students of Brooks were being kept in contact with, and inspired by, a spirit which had survived as a legacy, transmitted to this true naturalist from a former century.

Brooks' influence extended also to undergraduates and he impressed beginners in a manner which carries a lesson to our biological teachers. The routine of facts to be perceived was left to the books and the laboratory assistant; Brooks brought out in graphic lectures, the larger aspects of biology. With him, details invariably led to some interesting relation or law. He drew well and deliberately on the blackboard, and was direct, simple, and clear. The result was to give an impression of nature as a system of interesting problems, glimpses of life-histories, adaptations, and action. All was alive and presented by an intimate friend. The student listened to a master.

Many who may not be recognized as students of Brooks have thus had awakened in them an interest in nature, and an insight into her methods, which made a lasting impression upon them. This is affirmed by a number of those now conspicuous in the fields of medical science and practice who heard these lectures.

More than one undergraduate was diverted into a life-long devotion to biological science by this man who stood so steadfastly for the highest ideals of research in this field. His talks of nature were most persuasive, and presented to the minds of his listeners a vivid picture of the blue sea, the coral reefs, and the wonderful adjustments of the life with which they teem. This vision was so real as to supplant all ordinary motives of life, and inspire the sympathetic listener with the desire to follow the path of so genuine a leader.

It was not difficult to arouse his interest. Anyone who made a sane observation of nature could kindle it as readily as an ex- 
pert biologist; and if the observation happened to be foolish the reaction was often equally illuminating. In this breadth of interest we are reminded of Darwin.

It is strange that Brooks never published particularly on animal behavior. He was constantly alive to the interest and opportunities presented by this field, and urged several students to follow such studies; but the trend was, then, too strongly set toward morphological work to permit of their diversion into this other channel. I believe that his very special interest in the transformations and life-histories of echinoderms, liver-flukes, and insects, which has not been generally emphasized in accounts of his life, was greatly affected by the charm of observing the living larvæ and their reactions. His enthusiasm induced several men to work on these groups, as can be seen in a number of papers by students whose publications are not enumerated in these accounts.

It seems to me that it was this every-day intimacy with living things, and his insistent reflections on their adaptive responses, that attracted and held his students: This combined with a single-hearted devotion to a high standard of scientific work and thought.

1888-98 During my residence of ten years at the Johns Hopkins University, as undergraduate, graduate, and assistant, successively, I was thrown by fortunate circumstances into relations with Professor Brooks which ultimately assumed an intimate and personal character, and it is with deep appreciation and gratitude that, as I now look back upon those years, I realize the influence which he exerted upon me. He was one who set by his example the ideals which he wished his students to follow in scientific work. Many for the first time learned from him the real meaning of the "search for truth" as day by day in simplicity and sincerity he taught us through his own truth-loving nature veracity of thought and action. Many, too, learned under himfor the first time to take a philosophic outlook on zoölogical phe-

\footnotetext{
- Professor George Lefevre, University of Missouri.
} 
nomena. And his life was such that it made all around him feel in some measure the charm of the naturalist's calling.

Although the great and lasting debt, which all who came under his instruction owe to him, springs from the inspiration that unconsciously passed from him to us, it was his personal qualities, his gentleness, his kindliness, his thoughtfulness of others, as well as the quaint humor that characterized so many of his acts and sayings, that humanized and endeared him to his students. His capacity for sympathy was never shown more strikingly than during those dark days that followed upon the death of Professor Humphrey and Dr. Conant from yellow fever after the disastrous expedition to Jamaica in 1897. All who were there at the time will recall how deeply moved he was, nor will any of us be likely to forget the simple sincerity of the man as he stood among us and talked of the nobility of the sacrifice of a life for the sake of others and for the cause of science.

I think my earliest definite recollection of Professor Brooks is of seeing him walk into the lecture room in an undergraduate class wearing a long rubber overcoat which he proceeded at once to use on himself for the purpose of illustrating the morphological relations of the squid's mantle, while holding out the upturned collar to demonstrate the position of the siphon. I still have my notes on his undergraduate lectures and in reading them over I am struck afresh by the recollection of their clearness and beauty, although the subjects upon which he talked before the class followed each other without apparent order or relation. As I later learned while acting as his assistant, he was apt to lecture upon anything that he happened to be thinking about at the time, not infrequently changing the subject at the very last moment, to the dismay of the assistant who would then have to prepare hastily an entirely different set of charts and specimens from those which he had been previously instructed to have ready.

When I began my graduate work in zoölogy, I was, like every one else at the start, cast adrift, to sink or swim; and for all one knew at the time, Brooks seemed absolutely indifferent as to the outcome. He had given me a bottle containing a few shriveled and collapsed specimens of Doliolum, with instructions to work 
on the proliferous stolon. I remember with mortification how I floundered helplessly through the first few months in what appeared to me a hopeless struggle to reach solid ground, until one day I happened to find out something new about that stolon. It was a very trivial point, but in the exuberance of my first discovery I showed it to Professor Brooks, and from that moment his attitude toward me changed as if by magic. I was f r rthwith consecrated to the study of the Tunicata. Brooks had, however, the habit of suddenly suggesting and urging upon a student a totally different problem from the one upon which he was working, and this caused the greatest consternation among us during our earlier years, until we found by experience that he usually forgot about the matter in a few days. In this connection I cannot refrain from quoting from a letter which he wrote me from Baltimore while I was absorbed in studying the embryology of Appendicularia at the Beaufort Laboratory in the summer of 1895 . "I have just heard from Bigelow," he wrote, "that the medusa which I have been studying (Gonionemus) is now abundant in the Eel Pond at Woods Hole. If you could get the embryology and metamorphosis, it would make a fine thesis, and I write in the hope that you may be disposed to go to Woods Hole at once to try to study it, and to get specimens of the adult for me." The idea of dropping all of my work and setting out on a journey from North Carolina to Massachusetts to collect jelly fishes did not appeal very strongly to me, and I remained in Beaufort, but just how I escaped from the situation, which was quite embarrassing at the time, I do not now remember.

The recollections of Professor Brooks that are the most vivid and interesting ones to me are chiefly associated with our summers at the marine laboratories, for it was there, away from the routine and greater restraint of the life in Baltimore, that we came to know him most intimately and affectionately. In the daily companionship with him, for he constantly shared with us both the joys and hardships of the work, the lovable side of his nature was conspicuously open to us. A thousand incidents associated with him at Beaufort crowd my memory as I recall him there, the center of our life, the enthusiastic naturalist, the wise coun- 
sellor and teacher, the sympathetic friend, his droll humor always in evidence, but with never a trace of unkindness. I remember a day when one of the men, a rather puritanical student, who had been struggling with some refractory material, in a moment of discouragement told Professor Brooks that he could do nothing with it. In his characteristic way he made no reply at the time. but some hours later returned and said quietly, "Did you evertry swearing? That helps sometimes."

Most delightful of all is the recollection of long evenings on the verandah, where, after the day's work was done, we sometimes sat listening to his talk on nature and philosophy. True it is that we were not always able to follow him closely in his metaphysical moods but we learned at least to feel something of the relation that exists between the study of phenomena and the philosophic inquiry into underlying causes.

1900-05.7 To work on aphids, to read Witlaczil, these were ny first instructions. After that he seemed to have lost interest in me; and he showed none in aphids. Months later he startled me by suddenly proposing three elaborate dissections, a study of the lamellibranch gill, and of the brooding habits of Cyclas.

To improve his pedagogy seemed an easy thing at that time; to-day I am thankful that he left me alone, and neither pushed nor pulled. Into the sea of work suggested I plunged, bat Brooks furnished no life-belts. Instead he gave opportunity, and something more.

In my time the "Foundations" were being read, discussed, and not wholly understood. The typewriter in the laboratory and at Brightside, clicked incessantly. The Lowell Lectures were in the making; bulky translations from Hertwig and from Heider were completed though never published; many essays and shorter papers were written; Berkeley was quoted; and the pile of incoming reprints remained unclassified on the floor.

He seemed to be writing much, and the larger problems, for the time, triumphed over the microscope. The doom of his morphological studies was practically sealed by illness that grad-

\footnotetext{
${ }^{7}$ Professor Otto C. Gilaser, University of Michigan.
} 
IVilliam Keith Brooks

student ut Williams College

1868 
wether and tear he tom

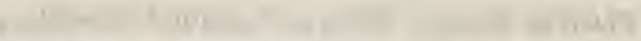

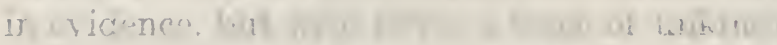

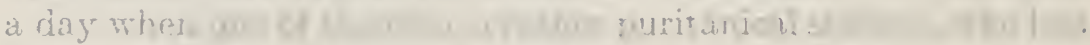

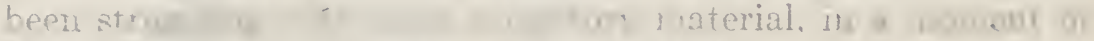
dispoun

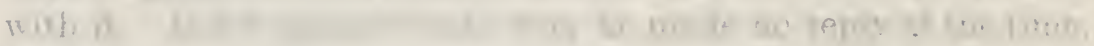

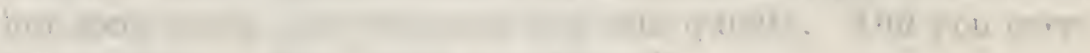
(1)

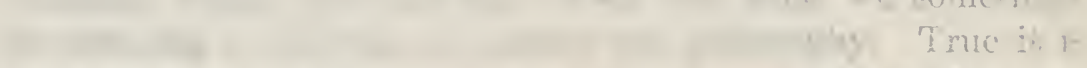

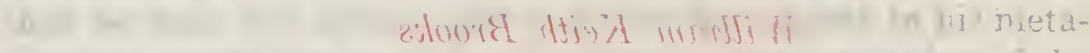
net noxet

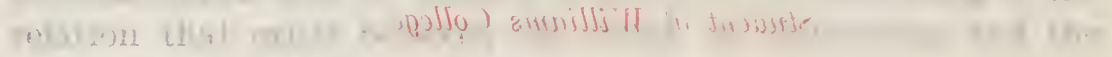

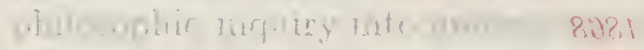

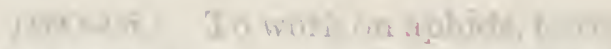

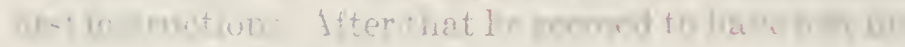

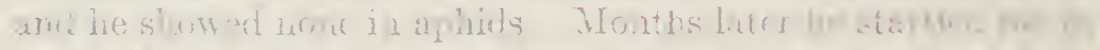

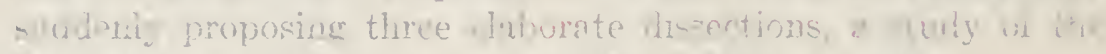

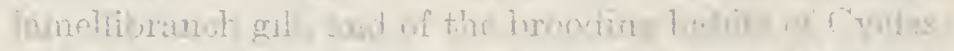

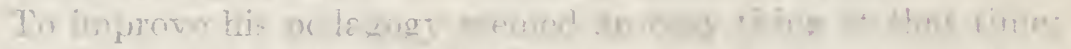
forday I orat th

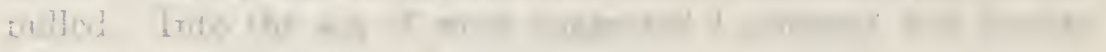

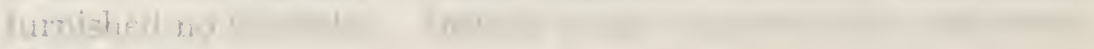
While motro

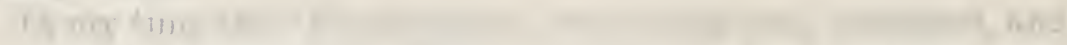

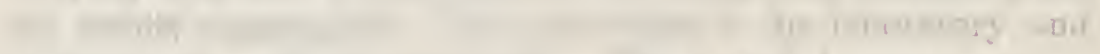

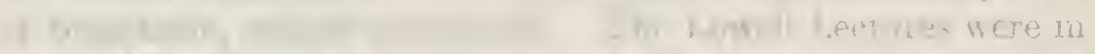

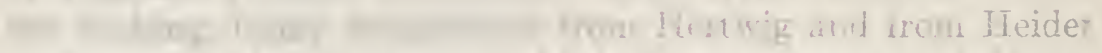

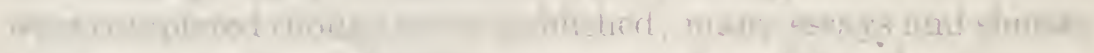

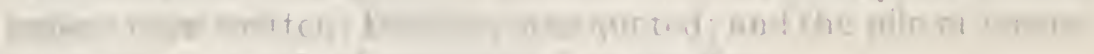

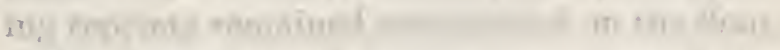

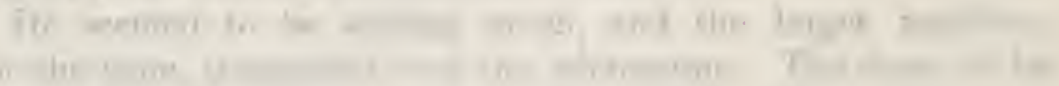

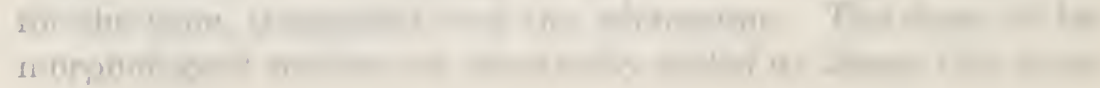




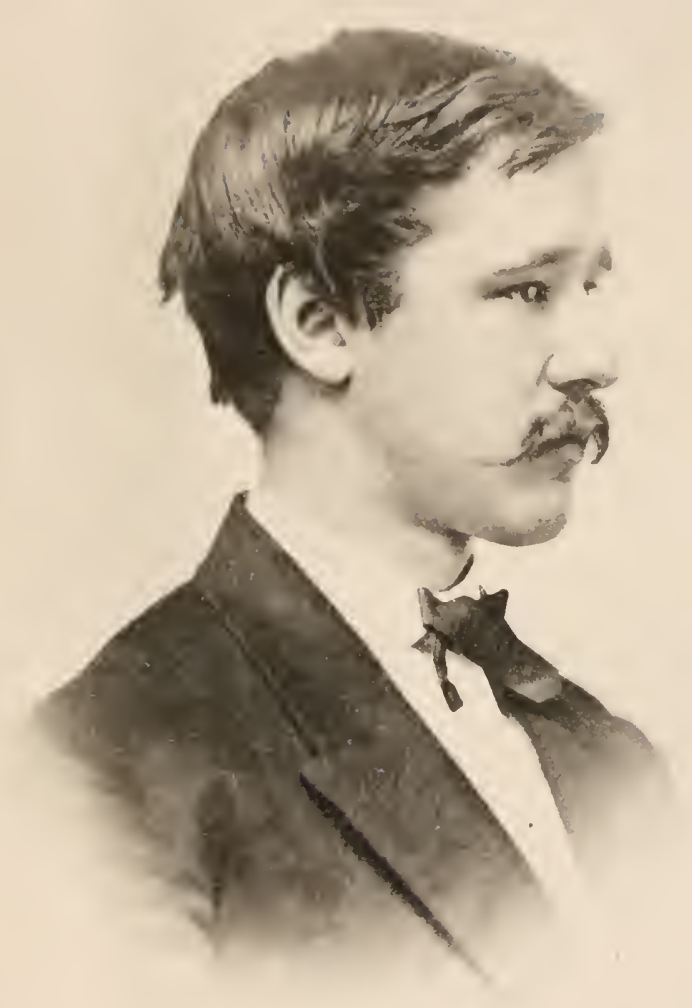



ually became worse, until his system, enfeebled by a weak heart, scarcely resisted the other difficulties that began to burden him. It is true that periods of improvement alternated with those of depression, but the doubt that hovered over him cast its shadow through the laboratory. It was at this time that Mrs. Brooks died.

Such health as he had known, never came back wholly, and months passed before interest in life and work returned. With renewed vigor he studied his hydroids, his salpas, and the oyster, began to complete researches half-forgotten, and to start new ones. 'The Sunday evenings at Brightside, too, were resumed, and amid clouds of smoke, he read Berkeley or his own writings. This was Indian summer.

At home, much of his most vital teaching was done. Stretched comfortably in his steamer chair, in full view of the books and pictures that he loved, and surrounded by a family, not in the narrow sense, but one in which his students, his negro servants, his dogs, and his flowers had each a place, he was thoroughly at ease. Often, as he laid his hand affectionately on Jupe's great head, he spoke with tenderness of the details of his home-life.

If one thing must be singled out to explain the affection he inspired, it is that he himself was affectionate. 'The loyalty that led him to give of his own small income in times of need and made him speak of former students as though they had been with him only yesterday, included other things, his science, his duties as a teacher, and his university. In its period of hardship he economized, and offers from other institutions did not shake him.

His interests were human, and his science a pathway along which he walked in humility to view the world and to interpret it. The great problems were not mere exercises for the mind, but human difficulties. The teacher and the man were inseparable and it was no less the man than the teacher who inspired others.

1905-08.8 It was during Professor Brooks' declining years that he honored me with his friendship. On these visits of his to the

${ }^{8}$ Dr. A. G. Mayer, Carnegie Institution of Washington. 
Carnegie Laboratory at Tortugas I was much impressed with his broad kindliness and tolerance of spirit and with his interest in the world. The force and independence of his character also were obvious and it was clear that he would have been a deep student of living things under any conditions of life. He was a thinker even more than an observer. He was the follower of no school, and few men have been so little dominated by the thoughts of the world around them.

Still it was not his power and originality alone that made him great and reverenced among us. It was his spirit that led us onward in our science. The little boy who studied dragon flies in the pool of his father's yard had had many years pass over him, yet in his simple wondering love of nature he remained as in his childhood days. This deep reverence for the universe of which he felt he formed so small a part, made him careless of many things we deem important in our daily life, for his thoughts were not upon things of the moment but were far beyond in the borderland between the known and the unknown.

\section{THE CHESAPEAKE ZOÖLOGICAL LABORATORY ${ }^{9}$}

Professor Brooks' early experience at Penikese under Louis Agassiz must have had a great effect upon him. From that time on his interest in marine zoölogy was one of the dominant influences in his life. One of his first important acts at the Johns Hopkins University was to organize (in 1878) a movable seaside station under the name of the Chesapeake Zoölogical Laboratory and during the following twenty-eight years he was constantly to be found during the warmer season at some point on the coast or in the West Indies accompanied by a party of students, all engaged in the study of marine life.

The importance of this Laboratory in the development of the biological department of the Johns Hopkins University and in the general advance of zoölogy in America may be estimated from the large number of students who worked at the laboratory and

\footnotetext{
? Professor E. G. Conklin, Princeton University, in National Academy Biographical Memoirs, vol. 7.
} 
the large number of papers which they published. Doctor Brooks expected all of his graduate students io spend a season or more at this laboratory. He rightly estimated such work as the most valuable experience a beginner could have, for in this way the student became acquainted with animals under natural conditions; he had the opportunity of laying a broad foundation for his future work as a naturalist, of finding for himself some mat vers to investigate, and thus early to acquire the mental habit of the independent investigator.

The Chesapeake Laboratory, as said, was not limited to one place. For the first few year's of its existence it was located at several different points on Chesapeake Bay; afterwards it was located at Beaufort, North Carolina; then at different places in the Bahama Islands, and finally in Jamaica. In the various expeditions of Brooks and his students to these different places they made not only a biological survey of each region, but they did work of most fundamental and far-reaching importance on the various groups of animals found. Out of these expeditions has grown the beautiful and permanent station of the U. S. Fisheries Bureau at Beaufort, North Carolina, in which Brooks took great interest and pride. It was on these expeditions that his students came to know him most intimately and affectionately. In the memory of each of them is fixed some scene of his enthusiasm over the discovery of a rare form or of an unknown stage in some life history; his long vigils full of exciting discoveries; his quiet talks on nature and philosophy.

The Chesapeake Zoölogical Laboratory occupied so large a place in the life and work of Professor Brooks that it seems desirable to reproduce here, in his own words, a more detailed account of the aims and history of that laboratory during, its first nine years. The following is taken from a report by Professor Brooks on "The Zoölogical Work of the Johns Hopkins University, 187886," published in the Johns Hopkins University Circulars, vol. 6, No. 54:

In natural science the policy of the University is to promote the study of life, rather than to accumulate specimens: and since natural laws are best studied in their simplest manifestations, much attention has been 
given to the investigation of the simpler forms of life, with confidence that this will ultimately contribute to a clearer insight into all vital phenomena.

The oldest forms of life are marine: every great group of animals is represented in the ocean, while many important and instructive groups have no terrestrial representatives; onitting the insects, more than fourfifths of the known species of animals are marine, and the total amount of animal life in the ocean is incomparably greater than upon the land. In a word, the ocean is now, as it has been at all stages in the earth's history, the home of life; and it is there, and there only, that we find the living representatives of the oldest fossils, and are thus enabled to study the continuous history of life from its simplest to its most complex manifestations.

On the sand flats at the mouth of the Chesapeake Bay, we find, living side by side, animals like Lingula, 'Amphioxus, Limulus and Balanoglossus, which are the representatives of some of the oldest and most primitive types of animal life; and all attempts to trace out the natural relationships of any group of animals, lead us at once to forms which are found only in the ocean.

The animals which have contributed most extensively to the formation of the earth's crust, the corals and foraminifera and radiolarians, abound in the ocean to-day, and it is only by studying their life, by observations at the seashore, that we can understand and interpret their geological influence.

Nearly every one of the great generalizations of morphology is based upon the study of marine animals, and most of the problems which are now awaiting a solution must be answered in the same way.

For these reasons our chief aim in zoölogy and animal morphology has been to provide means for research upon the marine animals of the Atlantic coast, and for nine years, successive parties, composed of instructors, fellows and students in this department, together with instructors and advanced students from other institutions have spent at the seashore all the months in which marine work is practicable. Their time and energy have been devoted to research rather than to the preservation of collections, and the wisdom of this course can be estimated by examination of the accompanying list of publications [here omitted]; all of which are based, either in part or entirely, upon researches which we have carried on at the seashore.

The wisdom of our policy is well illustrated by the fact that the leading naturalist of America, himself the head of one of the largest scientific 
collections in the world, says in his annual report for $1884,{ }^{10}$ that the expenses of an immense natural-history collection are so great that it would be far cheaper, with the present facilities and the cost of travel, to supply the student with the necessary funds for valuable researches, than to go on for years spending in salaries of curators and the care of collections, sums of money which, if spent in a different manner, in promoting original investigation in the field or in the laboratory and in providing means for the publication of such original researches, would do far more tow ards the promotion of natural history than our past methods of spending our resources.

This fact has become widely recognized during the last ten years, as is shown by the establishment of marine laboratories by several of the European institutions of learning; and in the sunmers of 1883 and 1884 we had with us at our laboratory a young English naturalist (Wm. Bateson) who had been provided by the Royal Society of London with funds for his researches, the results of which have recently been published in England.

The Johns Hopkins University was among the first to recognize and act upon this new departure in zoölogy, and our little marine station is almost as old as the great Naples laboratory. Briefly stated its history is as follows:

In 1878 a small appropriation was made to enable a party of biologists from the University to spend a few weeks at the seashore in the st:idy of marine zoölogy. Through the influence of Maj. Gen. Q. A. Gillmore, the Secretary of War permitted us to occupy the vacant building at Fort Wool. Prof. Spencer F. Baird also exerted his influence with the Secretary of War in our behalf, and aided us in many other ways; furnishing us with dredging apparatus and with three small row-boats. The scientific results of our season's work were printed in an illustrated volume, the cost of publishing which was borne by the following citizens of Baltimore: Samuel M. Shoemaker, John W. Garrett, John W. McCoy, Enoch Pratt, P. R. Uhler, T. B. Ferguson, Dr. Geo. Reuling, President Gilman, Professor Martin and others.

In 1879 the appropriation for the maintenance of the laboratory was renewed, and in order to present an opportunity for studying the oyster beds of Maryland, the laboratory was opened in three of the barges of the Maryland Fish Commission at Crisfield, Maryland, a point which proved to be very unfavorable. Maj. T. B. Ferguson, the State Fish Commissioner, not only provided the barges for our accommodation,

10 Report of the Museum of Comparative Zoölogy, Cambridge, Mass. 
but he also fitted the steam yacht Lookcut with dredging apparatus, and rendered us valuable help in dredging and collecting. Through his influence a small steam launch was also detailed from the U. S. Navy for our use.

The next year the $\operatorname{Tr}$ sstees of the University voted to continue the laboratory for three years more, 1880-1-2, and they provided a liberal annual appropriation of $\$ 1,000$ for current expenses, which was renewed annually in 1883-4-5-6, and was expended in rent, wages, fuel, laboratory supplies, repairs, etc. They also appropriated the sum of $\$ 4,500$ for permanent outfit, and most of this was used in the purchase of two boats; a Herreshoff steam launch twenty-seven feet long and eight feet beam, and a center-board sloop forty-seven feet long and fourteen feet beam.

After an examination of all the available localities the town of Beanfort, N. C., about four hundred miles south of Baltimore, was selected as the site for the laboratory, and a vacant house, suitable for the accommodation of a small party, was found and rented as a laboratory and lodgings for the party, and it has been occupied during the seasons of 1880 1-2-4-5, and by two stildents in 1886. As the director was, in 1883, a member of the Maryiand Oyster Commission, the outfit of the laboratory was that year moved from Beaufort into the Chesapeake Bay, and we occupied a building which we rented from the Normal School at Hampton, Va. As Hampton proved to be a very unfavorable place for our work we returned to Beaufort the next year, and we have accordingly spent five seasons at Beaufort.

During the season of 1886 the zoölogical students of the University were stationed at three widely separated points of the seacoast. A party of seven under my direction visited the Bahama Islands, two were at Beaufort, and one occupied the University table at the station of the U. S. Fish Commission at Woods Hole.

The party which visited the Bahamas consisted of seven persons, and our expedition occupied two months, about half of this being consumed by the journey.

The season which is most suitable for our work ends in July, and we had hoped to reach the Istands in time for ten or twelve weeks of work there, but the difficulty which I experienced in my attempts to obtain a proper vessel delayed us in Baltimore, and as we met with many delays after we started, we were nearly three weeks in reaching our destination.

We stopped at Beaufort to ship our laboratory outfit and furniture, but the vessel, a schooner of 49 tons, was so small that all the available space was needecl for our accommodation, and we were forced to leave part of our outfit behind at Beaufort. 
We reached our destination, Green Turtle $\mathrm{K}_{\mathrm{c} y}$, on June 2nd, and remained there until July 1st. The fauna proved to be so rich and varied and so easily accessible that we were able to do good work, notwithstanding the shortness of our stay and the very primitive character of our laboratory. This was a small dwelling house which we rented. It was not very well adapted for our purposes, and we occupied as lodgings the rooms which we used as work-rooms.

\section{Record of the various sessions}

For the following brief records of the various sessions we are indebted in large part to Prof. E. A. Andrews.

1878: 8 weeks, Ft. Wool, Virginia; 7 members. Brooks studied embryology of Lingula.

1879: June 25-August 8, Crisfield, Maryland; 11 members. Brooks studied the oyster. Three barges served as laboratory and quarters. Swarms of mosquitos led to the abandonment of this locality early in August, and the removal of the laboratory to Ft. Wool, until September 15 .

1880: April 23-September 30, Beaufort, North Carolina; 6 members. Laboratory and quarters were in the Gibbs house. A steam launch was bought and the laboratory equipped by means of an appropriation from the University.

1881: May 2-end of August, Beaufort, North Carolina; 12 members. An "Elementary Seaside School" had been announced, with lectures by Brooks and S. F. Clarke; fee for the course, $\$ 25$.

1882: May 1-end of September, Beaufort, North Carolina; 8 members. 1883: May 1-October 1, Hampton, Virginia. As a member of the Maryland Oyster Commission Brooks was obliged to spend this summer on the Chesapeake. The new machine shop of the Hampton Institute was rented as a laboratory, and a fast sloop was added to the equipment. Wm. Bateson there joined the party to study the development of Balanoglossus.

1884: June 1-September 19, Beaufort, North Carolina; 10 members. The illness of Brooks obliged him to return after a month, leaving the laboratory in charge of $\mathrm{H}$. W. Conn. Bateson, who was again with the party, was also seriously ill.

1885: May 23-September 15, Beaufort, North Carolina; 11 members. Brooks became a licensed pilot to take the steam launch in and out of Beaufort Inlet. 
1886: June 2-July 1, Green Turtle Key, Abaco, Bahamas; 7 members. The party left Baltimore, May 1, in a small Bay schooner, chartered by the day, with Brooks as pilot. With head winds, mishaps and a stop at Beaufort to take on laboratory furniture they did not reach their destination until June 2.

1887: March 1-July 1, Nassau, Bahamas; 12 members. After this session, owing to financial losses on the part of the University, the Chesapeake Zoölogical Laboratory was temporarily suspended and its outfit dispersed.

1888 and 1889: Brooks, with some of his students, was at Woods Hole, Massachusetts, as naturalist in charge of the U. S. Fish Commission Station.

1891: May 26-September 1, Kingston, Jamaica; 15 members. The Chesapeake Zoölogical Laboratory was established at Port Henderson, on the harbor opposite Kingston.

1892: A party of three, in charge of Professor Andrews, was located at Alice Town, North Bimini, Bahamas. Brools did not go. 1893: April 20-July 23, Port Henderson, Jamaica; 7 members. Brooks did not go and Dr. R. P. Bigelow was acting director.

1894: April 7-July 7, Beaufort, North Carolina; 9 members. Brooks was present.

1895: June 6-August 13, Beaufort, North Carolina; 4 members. Doctor Sigerfoos was acting director; Brooks was not present.

1896: April 29-July 30, Port Henderson, Jamaica; 4 members. Dr. F. S. Conant was acting director; Brooks was there for a while.

1897: June-September, Port Antonio, Jamaica; 12 members. Prof. James Ellis Humphrey was acting director. Humphrey died there of yellow fever, August 12; Dr. Franklin Story Conant contracted the fever there, and died on his return to Boston in September.

1898: Beaufort, North Carolina; 6 members. Prof. H. V. Wilson was director. In this and all subsequent years students went, with little or no aid from the University, to the U. S. Fish Commission Station at Beaufort.

1901-1906: Brooks was again at Beaufort in 1901 and 1903, and at the Marine Laboratory of the Carnegie Institution at Dry Tortugas, Florida, in 1905 and 1906. 
PROFESSOR BROOKS AS AN INVESTIGATOR AND WRITER

Professor Brooks' invescigations lay mainly in the field of animal morphology and embryology. In this field he was an acute observer possessed of great patience and pertinacity. His philosophic insight and breadth of view, moreover, made him alert to the significance of what he observed, and his memoirs are hence notable for their suggestive and broad theoretical discussions. Fundamental resemblances in the development and anatomy of forms were the phenomena in which he was especially interested. Interrelationships between groups and the phylogenetic value of embryonic and larval characteristics were the speculative problems on which he brought his discoveries to bear. In reaching conclusions from facts he showed the caution of the observer who had seen much, and his soundness of judgment is widely recognized. Nevertheless he was at times not averse to bold speculation, as may be seen in his instructive discussion of the nature of the early pre-cambrian fauna, and the origin of the existing great groups of animals (The Genus Salpa and The Foundations of Zoölogy). His morphological studies embraced a number of invertebrate groups, pelagic tunicates, mollusks, molluscoidea, crustacea, and hydromedusæ.

The illustrations in Brooks' memoirs are striking. It was his practice to make them himself, and they have the artistic excellence combined with truthfulness of detail found only in the work of the artist-naturalist. Most of his drawings were in pen and ink, the shaded parts stippled, and made on a large scale suitable for reduction. They represented much labor, but Brooks was a quick worker in this style, which he preferred above all others. The mechanical process of stippling aided him, he maintained, to abstract his mind and to follow out lines of thought quite unrelated to the drawing. With respect to his artistic skill Brooks was without egotism, and when the drawings were once reproduced the originals were thrown away.

Together with skill in drawing Professor Brooks was unusually fortunate in possessing literary power in a marked degree. His subject is presented in an order and manner that makes it easy 
for the reader to follow, and his command of language is admirably suited to the needs of the naturalist. His technical papers always show order and proportion and a fine precision in the use of words. These qualities appear too in his one text-book, the "Handbook of Invertebrate Zoölogy," a manual so excellent that it has been a model for many later books in this field. His popular articles and lectures reveal the same logical habit of mind, but in these it is the graphic description that especially seizes the mind of the reader. Particularly pleasing and effective are the descriptions of scenes of nature in which animals dominate, or of the behavior of individual animals. In the argumentative portions of his later writings dealing with heredity and the philosophical aspects of nature, Brooks is not always easy to follow. He leaves a good deal of responsibility on the reader. Yet these writings contain much that is beautiful in style as well as in idea, much that is very quotable, real "nuggets of wisdom, products of deep thought as well as of careful observation."'11

Researches on the Tunicata. ${ }^{12}$ Brooks' first contributions on the Salpidæ appeared in 1875-'76. He observed that the eggs, which are borne by the individuals of the chain, arise really in the solitary Salpa and are passed into the stolon early in its development. Each individual of the chain receives usually one (in some species more) of these eggs and serves as nurse to the embryo which comes from it. Salpa, therefore, does not show true alternation of generations, and Chamisso's discovery of an apparent metagenesis in this form must be looked on as a misinterpretation of the phenomena. In his later study Brooks found that the spermatozoa as well as the eggs come from the mass of germ cells lying in the ventral part of the solitary Salpa, so that the solitary Salpa is in reality a potential bisexual animal.

Brooks worked out in far greater detail and with greater clearness than any other student the development of the buds upon the stolon, and showed the fundamental harmony of the process of

11 President D. S. Jordan.

18 Professor M. M. Metcalf, Oberlin College. 
budding in Salpa with that in Pyrosoma and in the Clavelinide among the ascidians. The stolon is bilaterally symmetrical, its planes of symmetry coinciding with those of the solitary Salpa which bears it, and at first the planes of symmetry of every member of the chain coincide with those of the stolon and the solitary Salpa. Very soon, however, a twisting of the chain occurs which leads to the formation of a double row of Salpæ, each row with the dorsal surfaces of its members turned outward while the ventral surfaces of the two rows are turned toward one another, and the right sides of the members of one row and the left sides of those of the other row are turned toward the base of the stolon.

He showed that the placenta of Salpa does not resemble the mammalian placenta in its method of nourishing the embryo, but that certain cells in the placenta, taking nourishment from the blood stream of the nurse (the chain Salpa), grow to very large size, then lose their connection with the placenta and wander to different parts of the embryo, where they break down and nourish the growing tissues of the embryo.

Salensky's generally accurate work upon the embryology of many species of Salpa contained one fundamental error, since he described the embryos as arising not from true blastomeres but from follicle cells, the blastomeres degenerating early in the developmental history. Brooks, recognizing the improbability of any such conditions, succeeded in tracing the development of the egg itself until from its blastomeres the organs arise. He found that the blastomeres develop very slowly; that the follicle cells, on the other hand, proliferate very rapidly and take on the form of the rudiments of the several organs, the organs being thus blocked out in these extra-embryonic cells, while as yet the blastomeres are very few in number. Later the blastomeres multiply and pass into the different parts of the mold thus formed for them by the follicle cells, and gradually use as food the degenerating follicle cells that surround them.

In his latest, unpublished work he traced the cleavage of the egg; he found a clear gastrula arising by invagination from the group of blastomeres; he observed the hollow dorsal nerve tube, finding it at first considerably elongated; he found a postero-dorsal rod 
of blastomeres, the notochord, which later for the most part passed into a postero-ventral protuberance there to degenerate and share in the formation of the eleoblast which he thus clearly showed to be a degenerate tail; at one time he was studying structures in some of his embryos which seemed to be a pair of true stigmata, but his final decision in regard to them is unknown.

Brooks' embryological work convinced him that Salpa, though now perfectly adapted for pelagic life, has not always been pelagic, but that it is descended from sessile forms like the ascidians, and that some of the features which so well adapt Salpa for a pelagic existence arose during this sessile stage in its ancestry, or were then much improved over the earlier condition illustrated in Appendicularia. Having found this most typically pelagic of all pelagic animals to be a migrant from the ocean bottom, he was led to review the whole pelagic fauna, and as a result of this review reached the conclusion that nearly all pelagic animals of considerable size or complex structure have had a similar history and are descended from forms that once lived on or near the ocean bottom.

The memoirs upon the Salpidæ are of such comprehensive character and fundamental importance that they must be designated as monumental. This massive character of his work, together with the soundness of judgment displayed, has unquestionably made Brooks the foremost student of the group. It is he, more than all others, who succeeded in showing that beneath the perplexing maze of secondary phenomena which so obscures the development of this group, there is a general conformity to the development of other chordates.

Researches on the Crustacea. ${ }^{13}$ Professor Brooks' interest in the Crustacea began early, for as a boy he had collected the freshwater shrimp, Palaemonetes exilipes, in the Rocky River near his Cleveland home, and in the marine laboratory of Alexander Agassiz he had observed with astonishment "the lively interest in shells," displayed by the newly hatched hermit crabs. That

13 Professor F. H. Herrick, Western Reserve University. 
the impressions thus made were strong may be gathered from the fact that many years later he urged the writer to study the development of this shrimp, if possible, and that after the lapse of nearly a quarter of a century he wrote the graphic account of the behavior of the hermit crab which appears in the introductory lecture of his work on "The Foundations of Zoölogy."

Altogether there are about fifteen papers on the embryology, metamorphosis, habits and classification of the higher crustacea which singly or jointly bear the name of Brooks, and all were issued during a period of fourteen years, from 1879 to 1892 . Moreover, his "Handbook of Invertebrate Zoölogy" contains much original matter pertaining to this class of animals. His first contribution in this field was on the larval stages of the stomatopod, Squilla empusa, and represented the first "Scientific Results of the Chesapeake Zoölogical Laboratory" for 1878, and it was upon the adults and the larvæ of this sub-order that some of his most notable work was later accomplished.

At Beaufort, North Carolina, during the season of 1880, Brooks' interest in Crustacea deepened, for he saw in their structure and in the metamorphosis which they so beautifully displayed, a means of attacking several larger problems, such as "the laws of larval development," the analysis of secondary adaptations, and the meaning of metamerism in both the lower and higher animals. He had pondered over the works of Professor Claus on crustacean development and morphology, and for upwards of four years, from 1880 to 1883 , his own elaborate notes and pen drawings on the Macrura had grown to such an extent that they filled a large portfolio. From this source he drew materials from time to time for publication, as certain subjects happened to engage his special attention. Without doubt he had contemplated an extended monograph, which was only partially fulfilled in the work on "The Embryology and Metamorphosis of the Macrura," published in 1892.

The works by which Brooks will be best known to all future students of crustacean zoölogy are undoubtedly his monograph on "Lucifer: A Study in Morphology," published in the Philosophical Transactions of the Royal Society of Great Britain for 
1882, and his "Report on the Stomatopoda," which appeared as part of the sixteenth volume of the Scientific results of the Challenger Expedition in 1886. In the former work, we are told that in April 1880, he found at Beaufort "a single Lucifer with two eggs attached to one of its appendages," and that he was "led by the great importance and interest of the subject to make every effort to trace its life-history." Success came only after months of repeated failure, when at last he could say with evident satisfaction: "I have seen the eggs of Lucifer pass out of the oviduct. I have seen the Nauplius embryo escape from the same egg which I had seen laid, and I have traced every moult from the Nauplius to the adult in isolated specimens. There is therefore no crustacean with the metamorphosis of which we are more thoroughly acquainted than we now are with that of this extremely interesting genus." Not only did he discover that Lucifer emerged from the egg as a true Nauplius, but what was even more novel, that the egg underwent a total and regular segmentation, and gave rise to an egg-gastrula of the invaginate type. After giving an exhaustive analysis of the developmental stages of Lucifer, and comparing its successive appendages with those of other representative Malacostraca, he concludes that the three-jointed Nauplius larva represents a true ancestor, that there is essentially but one kind of homology presented by metameric animals, and that, therefore, the remote ancestor of the crustacea does not represent a community of once independent parts.

The monograph on the Stomatopoda is distinguished by the great ingenuity shown in classifying all of the known larvæ of this sub-order, and in tracing them to their proper genera, for he had no living material to work with, excepting the two species from the southern coast of the United States, Squilla empusa and Lysiosquilla excavatrix, which he had previously studied, and which he used for exact comparisons so far as possible. He said of the collection submitted to him, that while it contained only fifteen species of adults, eight of which were new, it was very rich in larva. In speaking of the eggs, he remarked that since they were not carried about by the female, attached to her body or appendages, as is the rule in the higher crustacea, they quickly 
perished when deprived of the constant current thus supplied, and that it was very difficult to procure them at all, adding that he knew of no young Stomatopod which had been reared from an egg outside the burrow or in an aquarium.

The sentence just quoted was written in 1885, and we can appreciate the pleasure he must have experienced in being able to do the very thing to which he alludes, two years later at Nassau, for on the first or second day after reaching the Bahamas one of his students, Dr. E. A. Andrews, brought him "a Gonodactylus and a bunch of yellow eggs," which had been broken out of a coral rock. Feeling sure that at last he was on the track of a stomatopod's eggs, he started at once for the beach, and it was not long, as he tells us, before "the problem was solved, and I went home and to bed, confident that I should next day get all the embryological material I needed." The notable paper in which he has described how a stomatopod crustacean was for the first time reared from an egg, and followed in all its successive stages, alive, should not be overlooked, though appearing as a chapter in another work (The Embryology and Metamorphosis of the Macrura. Chapter III.).

Researches upon the Colenterata. ${ }^{14}$ Exclusive of preliminary accounts afterwards published in more amplified form, and of popular writings, Professor Brooks produced either alone, or in coöperation with his students, ten papers upon colenterates. All are the results of labors of his maturity, for he was thirty-two years of age when the first was published. This may account in some measure for the high standard he maintained throughout these papers, for next to Agassiz we must rank him as the greatest student of the colenterates of our country.

The excellence of his work depends not upon the number of species he described as new to science, for of these he names but eleven during the whole twenty-seven years covered by his writings on coelenterates. It is in the fields of embryology and anatomy that Brooks' work stands preëminent; and his life-histories of

14 Dr. A. G. Mayer, Carnegie Institution. 
Liriope, Cunoctantha, Eutima, and Philalidium McCradyi are classics of science in their thoroughness, wealth of accurate illustration, and that subtle charm in description which was their author's own. Through patient searching upon many a collecting trip at Beaufort, he was the first to find and describe the hydroids of Turritopsis, Nemopsis, Phortis, and Stomotoca, while his studies along the shores of the Chesapeake led to discovery of the ephyræ and early growth-stages of the free swimming medusa of Dactylometra.

His summers in the Bahamas led to the discovery of the remarkable process of the development of medusa-bearing hydroid blastostyles upon the gonads in Epenthesis (Philalidium) McCradyi. He also sectioned and beautifully figured, the marginal cordyli of Laodicea, and was the first to elucidate their structure and homologies; and from the standpoint of morphology his description of Dichotomia cannoides in the Proceedings of the American Philosophical Society of Philadelphia, 1903, may well serve as a model for those who essay to describe medusæ.

It was in coöperation with Brooks that Conklin discovered that in Physalia only male gonophores are found, while in another siphonophore, Rodalia, only female gonophores occur, the inference being that in both forms the opposite sex is so different from the one known that it may have been classed as a wholly different genus. Another of his students, Rittenhouse, while working under Brooks, gave an excellent account of the early stages of the developinent of Turritopsis.

Facts interested him but little unless they led toward generalizations, and thus it is that he wrote but one purely systematic paper upon cœlenterates, and that all of his other work was directed toward the study of developments and homologies as indicating what has been the path of evolution. Such a problem as the relationship between cœlenterates and bilateral animals was accordingly very attractive to him, and he was disposed to lay stress upon the (somewhat masked) bilateral symmetry discovered by himself in Eutima and by Hamann in other hydroids.

Brooks' views were not seldom in conflict with accepted theories, as when in $\mathbf{1 8 8 6}$ he came to the conclusion that the remote ances- 


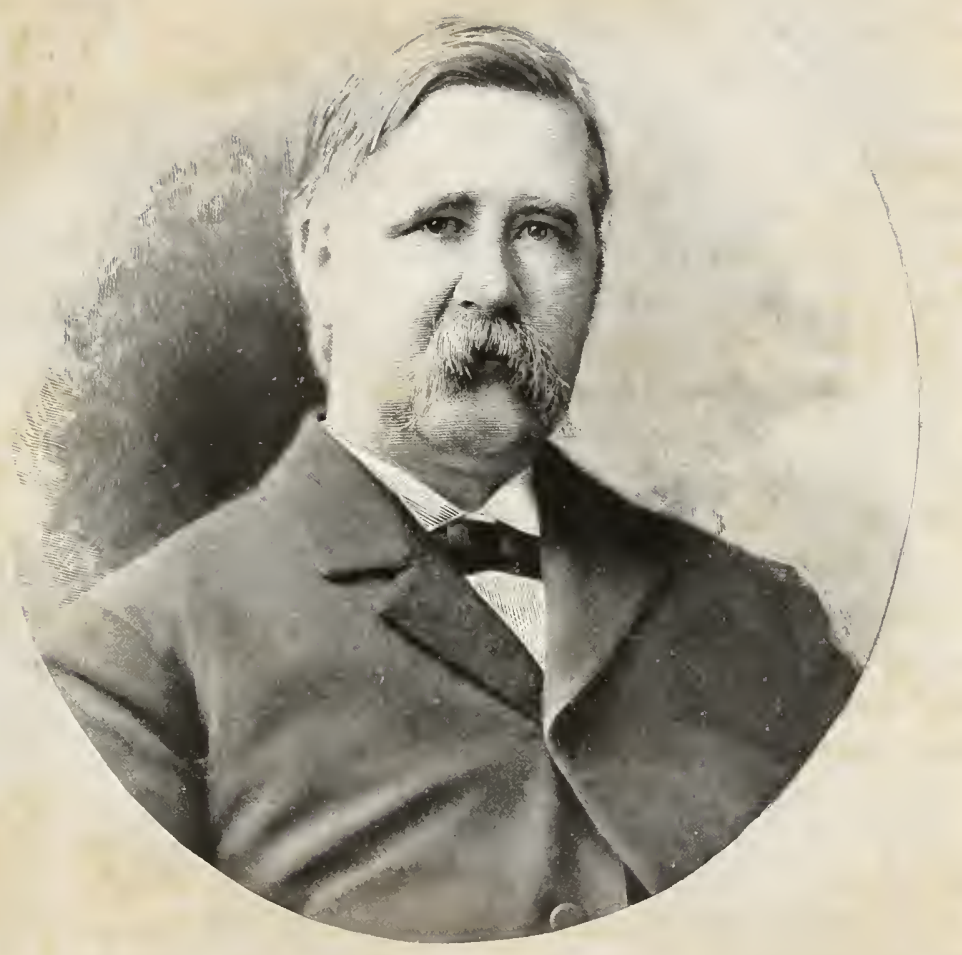

Reproduced trom Appletons' Popular Science Monthly. Copyright, I 899, by D. Appleton and Company

WILLIAM KEITH BROOKS 

tor of the hydromedusæ was a solitary free-swimming hydra or actinula with no medusa-stage but probably with the power to multiply by budding. Finally, however, becoming more perfectly adapted to a swimming life it was converted into a medusa with pulsating bell, and with sense-organs. After this the larva derived an advantage through attachment, and thus the hydroid stage was secondarily produced, and then perpetuated through natural selection. It may be said of this theory that while it has gained no important following, yet nevertheless it has never been disproven. It is logically sound, presents the direct development of certain medusæ from a new point of view, and the future may possibly show that it rests on a basis of truth.

Researches on the Mollusca and the Molluscoiden. ${ }^{15}$ Two of Brooks' first papers deal with the lamellibranchs, one(1874) with an "organ of special sense" in Yoldia, while in the other (1875) the development of Anodonta implicata is described in outline, and the conclusion is reached that the larva, Glochidium, is a specially modified stage and has no bearing on the question of the origin of the group. In a paper "On the Affinities of the Mollusca and Molluscoidea" (1876) he again approached phylogenetic problems, and concluded that the Brachiopoda have been derived from Vermes, Polyzoa from Brachiopoda, and the molluscan veliger (prototype of the Mollusca) from Polyzoa. Later in his paper on the development of Lingula (1879) he held that the Rotifera, Polyzoa, and Veliger were three branches which early diverged from the vermian stem. The Brachiopoda he held to be the most highly specialized members of the polyzoan branch, the Mollusca the most highly specialized of the Veliger branch. For these three branches he proposed the name Trochifera.

In his "Observations on the Early Stages in the Development of Fresh-Water Pulmonates" (1879) he observed the rhythmical nature of the process of cleavage, and devoted considerable attention to the origin of the germ layers, to the fate of the blasto-

15 Professor G. A. Drew, University of Maine. 
pore, and the origin of the digestive tract. The technique necessary for the successful sectioning of such small bodies as snail eggs had not been developed at this time. Brooks' observations were therefore made exclusively on material studied in toto, and it is interesting to find that this method of study led him into several serious errors. In his paper on the "Acquisition and Loss of a Food Yolk in Molluscan Eggs," Brooks devoted much attention to what is now known as the yolk lobe, or polar lobe, which he regarded as a food yolk which is disappearing in some forms, while in others it is being acquired. In a brief paper on the "Development of the Digestive "Tract in Mollusks" he reiterates his mistaken view that in gasteropods and lamellibranchs the blastopore is converted into the shell gland. Not until 1908 did he return to the gasteropods, publishing in that year in association with Bartgis McGlone, one of his students, a paper on the origin of the lung in Ampullaria.

Brooks has two papers on the development of cephalopods published in 1880. His important conclusions in these papers deal with the homologies of the cephalopod yolk sac, siphon, and arms. Numerous publications deal with the development and propagation of the oyster. In 1878, during the first session of the Chesapeake Zoölogical Laboratory, he attempted to find young oysters in the gills of the female, as had been described for the European oyster, but without success. In May, 1879, he went to Crisfield, Maryland, the center of the oyster industry on the Chesapeake, and settled down to study the problem of the development of the oyster. He soon learned that artificial fertilization was possible, and that the American oyster normally discharges its eggs and sperm into the open water, where the processes of fertilization and development go on independently of the parents. The results of his embryological studies on the oyster were published in full in a report to the Maryland Fish Commission (1880). This paper was very favorably received and was republished in whole or in part in many American and European journals. In recognition of the importance of this work he was awarded a medal by the Sociéte d'Acclimatation of Paris. 
Economic Worl on the Oyster Fisheries. ${ }^{16}$ Brooks' economic work on the oyster began in 1882 when the Governor of Maryland appointed him Chairman of a Commission to examine the oyster beds and to advise as to their protection and improvement. While occupying this position, he was excused by the Johns Hopkins University from practically all duties as teacher and investigator and for two years he devoted his talents and energy to the work of the Commission. He organized and carried on an extensive investigation of the actual condition of the natural oyster beds of Maryland and studied carefully the results of the policy then pursued by the State in its work of supervising and policing its oyster resources. He also compiled statistics from the history of the oyster industries of France and the North Atlantic States in order to ascertain and to show the possibilities of oyster production possessed by the tide waters of Maryland and the conditions under which some of these possibilities may be realized.

A detailed account of these investigations was published in January 1884 under the title "Report of the Oyster Commission of the State of Maryland" (a quarto volume of 193 pages), and carefully prepared plans for inaugurating a system of oyster culture under private ownership and for increasing the supply of oysters from the public oyster grounds, were submitted to the General Assembly for its consideration and approval.

The plans worked out by Brooks by which the oyster resources of the Chesapeake Bay and its tributaries could be husbanded and developed, were far in advance of public sentiment in Maryland and were rejected. Not until 1906, twenty-two years later, did the Legislature enact a general oyster culture law for the entire State.

Professor Brooks' active interesc in the Maryland oyster problem did not end when his connection with the State Commission expired. He realized from the character of the discussion and opposition which brought about the rejection of his plan for oyster culture, that the oyster problem in Maryland is in reality a social and political one, and he therefore set about conducting a

${ }^{16}$ Professor Caswell Grave, Johns Hopkins University. 
long campaign of education. In this he had in mind to bring the State to realize the value of the Chesapeake for oyster production, and the worth of proper methods of supervision and cultivation. He was available for semi-popular lectures, wrote magazine and newspaper articles on the subject of oyster's, and in 1891, published a treatise entitled "The Oyster," a little book that had wide influence and which was characterized by President D. C Gilman as "a memoir in natural history and a chapter" of political economy," in which the life history of the oyster is described "in terms scientific enough to be accurate, not so scientific as to be hard of understanding."

Dr. Brooks' efforts during this period resulted in the creation of an intelligent appreciation on the part of the general public not only throughout Maryland but in all of the Atlantic States as well, of the value and possibilities of the natural resources of tidal waters for the production of oysters, and men of large influence were enlisted in the cause of oyster culture. This deep cumulative influence of Professor Brooks on the public mind made him one of the most valuable citizens Maryland has ever had. Others carried to completion the task of crystallizing sentiment in favor of oyster culture, and finally in 1906 the Maryland Legislature passed a law for the protection and propagation of oysters along substantially the line that had been advocated by Brooks. The long campaign was thus happily terminated.

Contribution to Anthropology. ${ }^{17}$ Brooks' paper "On the Lucayan Indians" embodies the results of an excursion into the field of physical anthropology made during two visits to the Bahama Islands in connection with his summer laboratory. Very characteristically, he became interested in the history of the islands and in the people who dwelt there when they were discovered by Columbus. The skeletal fragments which there is reason to believe represent remains of the aborigines are very few. The material which Brooks had, and which was found in caves on the islands, consisted of three well preserved skulls and some

${ }_{17}$ Professor H. H. Donaldson, The Wistar Institute. 
other bones and fragments of bones. From these he was able to determine several of the more important physical characters of that ill-fated people who have left but a single monument, the word "hammock."

In the paper in question, which was read before the National Academy in November, 1887, Brooks gives a series of admirable plates artistically illustrating the skulls described, and reaches several conclusions, which may be summarized as follows: The bones are thick, massive and dense; the skulls are of good size. They are highly brachycepha!ic but at the same time artifically deformed in a way which would increase their brachycephalic shape. There is no reason to think that the people were gigantic, though they were probably of large size. From certain similarities to the remains of the inhabitants of southern Florida, it is probable that the Lucayans belonged to the same race.

Studies on Heredity. ${ }^{18}$ As early as 1876 in a paper entitled "A Provisional Hypothesis of Pangenesis" Brooks began to deal with questions of heredity and variation. His thinking in this direction took shape and led in 1883 to the publication of a volume under the title of "The Law of Heredity." The central point in the theory here presented is the conviction that the reproductive elements are, contrary to the usual opinion, not alike in function. In support of this conclusion the author draws arguments from the facts that hybrid offspring resulting from reciprocal crossings are often very different; that the offspring of a male hybrid and the female of a pure species is much more variable than the offspring of a female hybrid and the male of a pure species; that a structure which is more developed or of more functional importance in the male parent than it is in the female parent is very much more apt to vary in the offspring than a part which is more developed or more important in the mother than it is in the father. These and other facts convince Brooks that the ovum and sperm cell are not only different morphologically, but that they differ profoundly in function as well. 
In developing this idea into an explanatory theory of the way in which hereditary transmission is accomplished, Brooks borrows from Darwin's hypothesis of pangenesis, and assumes the existence of material particles, "gemmules," which are thrown off from the body cells. Unlike Darwin, however, he assumes that such particles are only thrown off at particular periods, when the body cells are disturbed in function through some change in their environment. The gemmules may penetrate an ovum or a bud, but it is the male germ cell which has gradually acquired during the evolution of the metazoa the peculiar power to gather and store up gemmules. The ovum on the other hand has acquired a very different nature. It contains material particles which correspond to the hereditary characteristics of the species. Thus in the case of a fertilized egg, as in that of a parthenogenetic egg, the great bulk of the development is due to the properties of the ovum itself. The gemmules brought in by the sperm cell unite with homologous particles in the ovum and so composite particles are produced which, as the egg segments and develops, give rise to cells that are strictly hybrids and which therefore exhibit variation. The ovum thus is the conservative element which transmits the characteristics that have already been acquired. The male cell is peculiarly that which stores up the disturbing effects of a changing environment. It especially leads, therefore, to variability in the offspring, to the production of individual differences.

This ingenious hypothesis enables Brooks to explain a great variety of inheritance phenomena and to overcome several serious objections to the unassisted selection theory. Whatever truth there may or may not be in the special ideas of the book, it remains to-day a stimulating and suggestive contribution, and it is properly looked on as one of the factors that have in recent years focussed the attention of the biological world on the problems of heredity.

Minor papers dealing with heredity and evolution, the cause: of variation, and the determination of sex, appeared from time to time. Sections of the "Foundations of Zoölogy" (1899) show, too. that Brooks' interest in the questions discussed in the "Law of 
Heredity' remained active during life. Two of his last addresses (1906-1909) deal with our concepts of heredity and variation. In these he emplrasizes the fact that the nature of an organism is not implicit in the egg, or in the organism indeed at any time of its life, but that it depends on a continuous reciprocal interaction between the organism and its environment. Such interaction leads in any particular case to a result which could not be calculated from a knowledge, however complete, of the egg itself since it is dependent not only on the organism but on the action of the total environment. The outcome of such interaction is the production of individuals which are never quite alike, although they may resemble one another closely. The occurrence of likenesses, or inheritance, and the occurrence of differences, variation, are thus not two processes but two views of the single process of reciprocal interaction. 'The idea that they are distinct is an error' into which we fall through concentrating our attention at one time on the resemblances, and again on the differences between individuals. These considerations, he thinks, show the uselessness of theories which postulate an inheritance substance and explain individual differences as the result of various combinations of its particles.

These addresses show that Brooks has in some measure shifted his standpoint since the time of the "Law of Heredity." He no longer is in a mood to employ evolution (determinant) hypotheses to account for development. He now looks on the development of the individual, and that of races also, as epigenetic in nature. What will be the outcome of an individual egg depends on the interaction between egg and environment, not on a determinate mechanism in the egg. The pre-cambrian fauna has given rise to the living beings of to-day. But the latter were not implicit in the former, for with the same ancestors the course of evolution might have been different had the sum total of environmental influences been different.

Writings on the Principles of Science. ${ }^{19}$ Brooks dwelt often in conversation and in minor writings, and always with an earnest

${ }^{19}$ Professor H. V. Wilson, University of North Carolina. 
pleasure, on the nature and intellectual value of what we can learn. His thoughts in this field of the principles of science were eventually embodied in his lectures on the "Foundations of Zoölogy" (1899). This remarkable book "belongs to literature, as well as to science. It belongs to philosophy as much as to either, for it is full of that fundamental wisdom about realities which alone is worthy of the name of philosophy.",20

Brooks was distinctly the philosophic type of naturalist. He was fully informed, critical, and constructive in special fields, but always aware that such fields were merely parts of a larger whole. Thus through the bent of his mind Brooks, the keensighted pioneer, and influential biologist, was also interested in and in thorough sympathy with life and living in all aspects, past, present and future, intellectual, emotional, and religious. Perhaps for that reason, too, he was a great teacher and inspirer of men.

The "Foundations" is essentially a discussion of the nature of scientific knowledge. It is the wise talk of an experienced, reflective naturalist of ripe years addressed primarily to younger fellow-workers in the fields of science. The argument which makes its way through pages and sometimes whole chapters of illustrations and digressions, interesting and suggestive in themselves, proceeds about as follows:

Our only knowledge of nature is through experience. Through experience we learn that one sort of event follows another, and this sequence, which we come to expect, constitutes for us the order of nature. Nevertheless there is no reason to believe that there is an inherent necessity in this order, for we never perceive the presence of any intrinsic causal connection between the preceding event (cause) and the succeeding one (effect).

When our knowledge of any part of nature has so far developed that we know the order of events, and so can predict the later steps in the series of occurrences, once the earlier have been noted, we say that we understand and can mechanically explain that particular set of phenomena. At present a gap separates vital

${ }^{20}$ President D. S. Jordan. 
from non-vital phenomena-to say that life is the sum of the physical properties of protoplasm is to make a dogmatic assertion, although to gainsay it is to make another. But with the progress of science this gap may be bridged over at some time. Should it be bridged over, and life in all of its aspects be found to be "protoplasmic," still we should not know why synthesis of compounds results in an organism or why a vital action is the outcome of protoplasmic changes. In respect to organisms and vital actions we should still be where we are now in respect to simple gravitation phenomena, for with respect to them all that we can say is that the stone will fall (if the future be like the past), but why it should fall we do not know.

This being the nature of our knowledge, present and future, what should the biologist seek to discover, and what are the problems that peculiarly concern him? Life is defined as a continuous adjustment of internal to external relations (Spencer), and it is pointed out that synthesized protoplasm, even were it capable of nutrition, growth, reproduction, and contraction, would not be a living thing if it were not also able to maintain persistent adjustment to the shifting world around it. The essence of the living thing and that which distinguishes it from other forms of matter is this very adjustment. Fitness, adaptive response, is therefore what we should seek to study in biology. The mechanism itself is of subordinate importance. Study it as we may, we cannot thus go far forwards, since our knowledge of nature never includes a perception of any necessary causal connection between events, such as would make it possible to discover vital phenomena by reasoning deductively from protoplasmic peculiarities. A corollary of practical import is that the naturalist should endeavor to study living things in connection with their environment.

Biology being thus defined as the study of adaptive response, the nature and evolution of man's reason and knowledge fall within its scope. For these are conceivably but the outcome of adaptive responses in the beginning as simple as the geotropism of a seedling's radicle. The ability, for instance, to make a distinction between what in practical life we call a truth, a real occurrence, 
and an error or illusion, is to be looked on as a useful response that has been acquired through selection. Man's knowledge, then, is of the peculiar kind that is useful to him. He may not yet know as much as is good for him, but he at least has acquired a store of the kind of knowledge that preserves him in the struggle for existence.

Viewing man thus from the biological standpoint Brooks attempts to deal with two human characteristics, the consciousness that the will is free and that the individual carries a moral responsibility. These, like all other vital characteristics, he thinks, may possibly sometime be shown to be part of the order of nature and in that sense mechanical . "Rational action may sometime prove to be reflex from beginning to end." And yet in the face of this possibility, Brooks would still maintain that the will is free and moral responsibility real. To some this will seem a difficult thesis.

Underlying the scientific inquiry as to the character of our present knowledge and of that which possibly we may acquire about nature, is the metaphysical question, "what is nature?" This question Brooks does not attack in the fashion of constructive technical philosophy. He makes no attempt to define reality. His purpose in dealing with the matter is plainly the practical one of showing us what we need not believe. He says in effect, if then our knowledge of all nature is and will continue to be of one sort, viz., that phenomena follow one another regularly and (supposing the future to be like the past) in predictable fashion, but without our ever learning why they so follow one another, there is not now nor will there be in the future any necessity drawn from science to believe in a fixed, necessary, determinate nature. If in any quarter it is imagined that the progress of science necessitates or may necessitate such a belief, this is a grave error: in his own words, "The belief that the establishment of scientific conceptions of nature shows that after the first creative act, the Creator has remained subject, like a human legislator, to his own laws, is based upon utter misapprehension of science, and upon absurd and irrational notions of natural law." In the second place we are in no wise forced to believe by anything in science that 
protoplasm and life are necessarily linked together: " . . . if it be admitted that we find in nature no reason why events should occur together except the fact that they do, is it not clear that we can give no reason why life and protoplasm should be associated except the fact that they are? And is it not equally clear that this is no reason why they may not exist separately?"

The next step in this survey and analysis of fundamental aspects of nature brings us to positive belief itself. As so often said, science quite fails to find in matter and motion any intrinsic virtue which sustains and directs the sequence of phenomena, and is absolutely restricted to thediscovery of the mere sequence which itself calls for (metaphysical) explanation. Hence there is nothing in science which has any bearing on the causal origin or on the reality of anything in nature, and we must go elsewhere for the foundations of the belief that we may entertain in respect to such matters. Brooks believes that "nature is intended" to be as it is, and is a language which a rational being may read. Since the rational being is perhaps himself a part of nature's mechanism, this is equivalent to saying that one part of the mechanism is cognizant of the purpose that animates the whole. This purpose is the effect of a power, a sustaining and directing intelligence outside nature, to which both the origin of nature and its maintenance from day to day are due. It is not something which once for all set a determinate cosmos spinning along the path of time with a full complement of "eternal iron laws." It is something which is at work now, under every phenomenon. This is obviously Brooks' belief, although being no propagandist he is far from enforcing it, indeed leaves it in a measure to be inferred. What he wishes to make plain is that science does not tell us why events happen a: we learn they do, and so it tells us nothing of rultimate reality. The question why the events we expect (from experience) should be those that come to pass concerns not science but "the natural theologian; for it is the same as the question, What is the Cause of Nature? To this all must seek an answer for themselves; for each has at his command all the data within the reach of any student of science." 


\section{LIST OF PROFESSOR BROOKS' WRITINGS ${ }^{21}$}

1864

Do animals reason? Wilkes' Spirit of the Times.

1874

A feather. Pop. Sci. Monthly, April, 1874.

1875

On an organ of special sense in the lamellibranchiate genus Yoldia. Proc. American Asso. Adv. Sei., Hartford meeting, August, 1874, 3 pp. 2 cuts. Printed Salem, 1875.

Embryology of Salpa. Proc. Boston Soc. Nat. Hist., vol. 18, Novcmber 17, 1875 , 7 pp., 1 pl.; also Monthly Microscopical Journal, London, July 1, 1876.

1876

Embryology of the fresh-water mussels. Proc. American Asso. Adv. Sci., Detroit meeting, 1875, $3 \mathrm{pp}$. Printed Salem, June, 1876.

A remarkable life-history and its meaning. American Naturalist, November, 1876,16 pp. 17 cuts.

On the development of Salpa. Bull. Mus. Comp. Zoöl., vol. 3, March, 1876.

On the affinity of the Mollusca and Molluscoida. Proc. Boston Soc. Nat. Hist., vol. 18, February 12, 1876, pp. 225-235.

\section{7}

A provisional hypothesis of pangenesis. American Naturalist, March, 1877, 4 pp. (Abstract of paper read at Buffalo meeting. American Asso. Adv. Sci., August, 1876).

Parthenogenesis in vertebrates and molluses. American Naturalist, October, 1877.

Instinct and intelligence. Pop. Sei. Monthly, September, 1877.

1878

Differences between animals and plants. Pop. Sci. Monthly, November, 1878. The condition of women from a zoölogical point of view. Pop. Sci. Monthly, June and July, 1879.

${ }^{21}$ Compiled by Prof. E. G. Conklin. Professor Brooks made no list of his publications and the following list has been compiled from many sources and may not be entirely complete. 
The scientific results of the Chesapeake Zoölogical Laboratory, session of 1878 . Baltimore, Murphy, 1879, 168 pp., constituting part 1, vol. 1, Studies Biological Laboratory, Johns Hopkins University, containing the three following papers by W. K. Brooks:

Preliminary observations upon the development of the marine prosobranchiate gasteropods; 47 pp., 1 pl.

The development of Lingula and the systematic position of the Brachiopoda; 70 pp., 6 pls.

The larval stages of Squilla einpusa Say; 5 pls.

The development of the digestive tract in molluscs. Proc. Boston Soc. Nat. Hist., vol. $19,1879,4 \mathrm{pp}$.

Abstract of observations on the development of the American oyster. Zool. Anzeiger, 1879.

Abstract of observations upon the artificial fertilization of oyster eggs, and on the embryology of the American oyster. American Journ. Sci., December, 1879. 3 pp.

Observations upon the early stages in the development of the freshwater pulmonates. Studies Biol. Lab. Johns Hopkins University, vol. 1, 1879, 26 pp., 4 pls.

Observations upon the artificial fertilization of oyster eggs and on the embryology of the American oyster. Ann. and Mag. Nat. Hist., London, 1880.

The biology of the American oyster. N. C. Med. Press, 1880.

The artificial fertilization of oyster eggs and the propagation of the American oyster. American Journ. Sci., 1880.

The development of the American oyster. Maryland Fish Commission Report, 1880,101 pp., 10 pls.

The development of the oyster. Studies Biol. Lab., Johns Hopkins University vol. 1, 1880, 115 pp., $11 \mathrm{pls}$. (Reprinted from the preceding.)

The acquisition and loss of a food yolk in molluscan eggs. Studies Biol. Lab., Johns Hopkins University, 1880, 7 pp., 1 pl.

Budding in free Medusæ. American Naturalist, 1880.

Embryology and netamorphosis of the Sergestidæ. Zool. Anzeiger, Jahrg. 3, 1880.

Amphioxus and Lingula at the mouth of the Chesapeake Bay. American Naturalist, vol. $13,1880$.

The young of the crustacean Lucifer, a Nauplius. American Naturalist, November, 1880 .

The development of the squid. Anniversary Mem. Boston Soc. Nat. Hist., 1880, 21 pp., 3 pls., 40.

The homology of the cephalopod siphon and arms. American Journ. Sci., vol. 20, October, 1880, 3 pp., 1 cut.

The rhythmical character of the process of segmentation. American Journ. Sci., vol. 20, 1880, p. 293. 
Du développement de la lingula et de la position zoologique des brachiopods. Arch. L de Zool. Exp. et Générale, 1881.

Lucifer, : Astudy in morphology. Proc. Royal Soc., April, 1881, pp. 1-3. (Ab- $\chi_{1}$ stract.)

Origin of the eggs of Salpa. Biol. Studies, Johns Hopkins University, vol. 2, 1882, pp. 301-312, 1 pl.

Lucifer: A study in morphology. Phil. Trans. Royal Society, London, vol. 173, 1882,80 pp., 11 pls.

Handbook of invertebrate zoölogy. 400 pp., 202 figs. Boston, Cassino, 1882.

Chamisso and the discovery of alternation of generations. Zool. Anzeiger, Jahrg. $5,1882$.

The metamorphosis of Alpheus. Johns Hopkins University Circulars, vol.2, no. $17,1882$.

On the origin of alternation of generations in Hydro-medusæ. Johns Hopkins University Circulars, vol. 2, no. 22, 1882; also Ann. and Mag. Nat. Hist., vol. $2,1883$.

The metamorphosis of Penæus. Johns Hopkins University Circulars, vol. 2, 1882; also Ann. and Mag. Nat. Hist., vol 2, 1883.

Speculative zoölogy. Pop. Sci. Monthly, December, 1882, and January, 1883.

On some methods of locomotion in animals. A lecture delivered to the employes of the Baltimore and Ohio Railroad Co., Baltimore. Printed by I. Friedenwald for free distribution among the employés of the Baltimore and Ohio Railroad Co., 20 pp., 10 cuts, 1882.

1883

List of Medusæ found at Beaufort, N. C., during summers of 1880-1881. Studies Biol. Lab. Jolıns Hopkins University, vol. 2, 1883, pp. 135-146.

Report of the Chesapeake Zoölogical Laboratory, summer of 1882.

The law of heredity. Baltimore, Murphy, 18s3, $336 \mathrm{pp}$.

Notes on the Medusæ of Beaufort, N. C., II: Turritopsis nutricula (McCrady). Studies Biol. Lab. Johns IHopkins University, vol. 2, 1883, pp. 465-475.

The first zoea of Porcellana. Studies Biol. Lab. Johns Hopkins University, vol. 2, pp. 58-62, pls. 6-7. (With E. B. Wilson.)

Alternation of periods of rest with periods of activity in the segmentation of eggs of vertebrates. Stuclies Biol. Lab. Johns Hopkins University, vol. 2, 1883, pp. 117-118.

The phylogeny of the higher Crustacea. Ścience, vol. 2, pp. 790-793; also New Zealand Journal of Science, vol. 2.

Reviews of work on cœelenterates in Weekly Summary of the Progress of Science. Science, vol. 1, pp. 50, 81, 230, 287, 344, and 553; Science, vol. 2, pp. 54, 692, 773, and 832 . 
1884

Is Salpa an example of alternation of generations? Nature, vol. 30, 1884.

()n the life-history of Eutima and on radial and bilateral symmetry in hydroids. Zool. Anzeiger, Jahrg. 7, 1884.

The development and protection of the oyster in Maryland: Report of the Oyster Commission of the State of Maryland, Annapolis, Maryland; 183 pp., 7 maps, 13 pls., $4^{a .}$

On a new law of variation. Johns Hopkins University Circulars, vol. 4, no. 35, December, 18s4, pp. 14-15.

A new law of organic evolution. Science, vol. 4, 1884, pp. 532-534.

1885

On the artificial propagation and cultivation of the oyster in floats. Johns Hopkins University Circulars, 1885, vol. 5, no. 43, p. 10; Also Science, vol. 6, 1885, pp. $437-438$.

Oyster farming in North Carolina. Forest and Stream, New York, 1885.

Influences determining sex. Pop. Sci. Monthly, January, 1885, pp. 323-330.

Can man be modified by selection? Pop. Sci. Monthly, May, 1885.

Abstract of researches on embryology of Limulus polyphemus. Johns Hopkins University Circulars, vol. 5, no. 43, October, 1885, pp. 2-5. (With Adam Bruce.)

Notes on Stomatopoda. Johns Hopkins University Circulars, vol. 5, no. 43, October, 1885, pp. 10-11.

A note on inheritance. Johns Hopkins University Circulars, vol. 5, no. 43, October, 1885, pp. 11-12.

\section{6}

Life on a coral island. Pop. Sci. Monthly, October, 1886; also Baltimore Sun, August 16, 1886.

The anatomy and development of the Salpa-chain. Studies Biol. Lab. Johns Hopkins University, vol. 3, 1886, 22 pp., 15 cuts. 2 pls.

Notes on the Stomatopoda. Ann. and Mag. Nat. Hist., vol. 17, 1886.

Report on the Stomatopoda collected by H. M. S. Challenger. Challenger Reports, vol. $16,1886,114 \mathrm{pp} ., 16 \mathrm{pls} .4^{\circ}{ }^{\circ}$

The life-history of the Hydro-medusæ: A discussion of the origin of the Medusæ and of the significance of metagenesis. Mem. Boston Soc. Nat. Hist., vol. $3,1886,67$ pp., 8 pls.

The zoölogical work of the Johns Hopkins University, 1878-86. Johns Hopkins University Circulars, vol. 6, no. 54, December, 1886, pp. 37-39.

The Stomatopoda of the Challenger expedition. Johns Hopkins University Circulars, no. 49.

Development and alternation of generations of the Hydro-medusæ. Proc. Acad. Nat. Sci., Philadelphia, March 3, 1886; also Science, vol. 7, no. 163. 
The scientific work of Adam Todd Bruce-A sketch. (In "Observations on the embryology of the insects and arachnids," by Adam Todd Bruce.) Memorial Volume, Johns Hopkins University Press, Baltimore, 1887.

1888

The life-history of Epenthesis MeCradyi, n. sp. Studies Biol. Lab. Johns Hopkins University, vol. 4, 18ss, 15 pp., 3 pls.

The growth of jellyfishes. Pop. Sci. Monthly, September (pp. 577-588, 7 cuts). and October, 1888.

On a new method of multiplication in hydroids. Johns Hopkins University Circulars, vol. 7, no. 63, February, 1888, pp. 29-30.

Note on the ratio between men and women. Johns Hopkins University Circulars, vol. 7, no. 63 , February, 1888, pp. 30-31.

\section{9}

Artificial propagation of sea fishes. Pop. Sei. Monthly, July, 1889, pp. 359,-367. A preliminary abstract of the researches of IV. K. Brooks and F. H. Herrick on the life-history of Stenopus. Johns Hopkins University Circulars, vol. 8, 1889.

The Lucayan Indians. Pop. Sci. Monthly, November, 1889, pp. 88-98.

$\checkmark$ On the Lucayan Indians. Mem. National Acad. Sci., vol. 4, no. 10, 1889, 9 pp., 12 pls.

What conditions are neccssary for the establishment by selection of a deaf variety of the human race? Report of the Royal Commission on the Blind, the Deaf, and the Dumb, etc; London, 1889.

\section{0}

On the relationship between Salpa and Pyrosoma. Johns Hopkins University Circulars, vol. 9, no. 80, April, 1890, pp. 55-56.

The structure and development of the gonophores of a certain siphonophore belonging to the order Auronectse. Johns Hopkins University Circulars, vol. 9, no. 88, 1890 . (With E. G. Conklin.)

Course of reading for graduate and spccial students in morphology at the Johns Hopkins University. Johns Hopkins University Circulars, December, 1890, p. 37.

\section{1}

The oyster. Johns Hopkins University Press, Baltimore, 1891.

On the early stages of cchinoderms. Johns Hopkins University Circulars, May, 1891, p. 101.

\section{2}

The embryology and metamorphosis of the Macrura. Johns Hopkins University Circulars, vol. 11, no. 97, April, 1892, pp. 65-72. (With F. H. Herrick.) (Introductory chapter of the following work.) 
The embryology and metamorphosis of the Macrura. Mem. National Acad. Sci., vol. $5,1892,135$ pp., 57 pls. (With F. H. Herrick.)

The English plan for the Columbus Marine Biological Station in Jamaica. Isetter to New York Daily Tribune, April 4, 1892.

The origin of the organs of Salpa. Abstract of chapter 14 of the Memoir on the genus Salpa. Johns Hopkins University Circulars, vol. 12, no. 106, January, 1893, pp. 93-97.

Aspects of nature in the West Indies. From the notebook of a naturalist. Scribner's Monthly, July, 1893.

The genus Salpa. Memoirs Biol. Lab. Johns Hopkins University, 1893, 303 pp., $46 \mathrm{pls} .4^{\circ}$

Salpa in its relation to the evolution of life. Studies Biol. Lab. Johns Hopkins University, vol. 5, 1893, pp. 129-212.

Maryland, its resources, industries, and institutions.

Chap. 7: Fish and fisheries.

Chap. S: The oyster.

The nutrition of the Salpa embryo. Johns Hopkins University Circulars, January, 1893, pp. 97-98.

The origin of the oldest fossils and the discovery of the bottom of the ocean. Jour. Geology, July and August, 1894; also Johns Hopkins University Circulars. January, 1895.

The origin of the food of marine animals. Bull. United States Fish Commission, 1894; The World's Fisheries Congress, Chicago, 1893, 5 pp.

Address, in proceedings of the convention to consider the oyster question, held at Richmond Chamber of Commerce, Richmond, Virginia, January 12, 1S94, pp. $33-37$.

An old naturalist-Conrad Gesner. Pop. Sci. Monthly, May, 1895, pp. 49-59, 12 cuts.

A review of Huxley's essays. The Forum, November, 1895.

An inherent error in the views of Galton and Weismann on variation. Science, vol. 1 , February 1, 1895, pp. 121-126.

Can an organism without a mother be born from an egg? Science, vol. 1, February 8,1895 .

The tyranny of the monistic creed, a review. Science, new series, vol. 1, April 5, 1895, pp. 381-384.

The sensory clubs or cordyli of Laodicea. Journ. Morphology, vol. 10, $17 \mathrm{pp} ., 1 \mathrm{pl}$. Science or poetry. Science, vol. 2, no. 40, October 4, 1895, pp. 437-440. 
The study of inheritance. Pop. Sci. Monthly, February (pp. 480-492), and March (pp. 617-626), 1896.

Woman from the standpoint of a naturalist. Forum, November, 1896.

Is there more than one kind of knowledge? Science, April 24, 1896.

The origin of the oldest fossils, and the discovery of the bottom of the ocean.

Smithsonian Report for 1894, pp. 359-376, Washington, 1896.

Logic and the retinal image. Science, March 20, 1896, pp. 443-444.

Lyell and Lamarck: A consideration for Lamarckians. Johns Hopkins University Circulars, vol. 15, no. 726, June, 1896, pp. 75-76. (Reprinted from Natural Science, February, 1896, vol. 9.)

Lyell. Johns Hopkins University Circulars, vol. 15, no. 726, June, 1896, p. 78. Budding in Perophora. Johns Hopkins University Circulars, January, 1896, p.

79. (With George Lefevre.) (Abstract of paper in National Acad. Sci., April 23, 1836.)

Note on anatomy of Yoldia. Johns Hopkins University Circulars, January, 1896, p. 85. (With Gilman Drew.)

Zoölogy and biology. Science, May 8, 1896, p. 708.

The retinal image once more. Science, April 24, 1896.

Lamarck and Lyell: A short way with Lamarckians. Natural Science, vol. 9.

Lyell and Lamarckism: A rejoindel. Natural Science, vol.9.

1897

The expedition to Jamaica in the summer of 1897 . Johns Hopkins University Circulars, November, 1897.

Testimony versus evidence. Science, vol. 2, no. 49, December 6, 1897, p. 771-773. William Harvey as an embryologist. Johns Hopkins Hospital Bulletins, nos. 77 and 78, 1897, $20 \mathrm{pp}$.

Anglo-Saxon versus Graeco-Latin. Natural Science, vol. 10, no. 63, May, 1897, p. 360 .

Migration. Pop. Sci. Monthly, April, 1898, pp. 784-798.

Zoölogy and the philosophy of evolution. Science, new series, vol. 8, no. 20s, December 23, 1898, pp. 881-893.

1899

The foundations of zoülogy. The Macmillan Co., New York, 339 pp.

Review of the "Wonderful Century," by A. R. Wallace. Science, April 7, 1899. The Wonderful Century-A Review. Pop. Sci. Monthly, November, 1899, pp. $25-31$.

Thoughts about universities. Pop. Sei. Monthly, July, 1899, pp. 349-355.

Mivart's Groundwork of Science-A Review. Pop. Sci. Monthly, February, 1899. 
Scientific Laboratorics: An address delivered at the dedication of the biological laboratory. Bulletin Westcrn Reserve University, October, 1899, $20 \mathrm{pp}$. (Reprinted in Bull. Johns Hopkins University, vol. 10, no. 104, November, 1899.)

Truth and error. Science, vol. 9, no. 213, January 27, 1899, pp. 121-126.

1900

The lesson of the life of Huxley. Smithsonian Report, 1900, pp. 701-711.

Review of "Marriages of the Deaf in America, by E. A. Fay, Volta Bureau, Washington, D. C., 1898." Pop. Sci. Monthly, January, 1900.

1902

Is scientific naturalism fatalism? Proc.Animeriean Philos. Soc., vol. 41, 1902.

The intellectual conditions for the science of embryology. Scicnce, new series, vol. 15, nos. 377 and 378, 1902, pp. 444-454, pp. 489-492.

1903

On a new genus of hydroid jellyfishes, Dichotoma. Proc. American Philos. Soc., vol. 42, 1903, 3 pp. 1 pl. (Read April 4, 1902).

1905

The oyster. A popular summary of a scientific study. (2d ed. revised.) John Hopkins University Press, 1905, 225 pp., 16 pls.

1906

Heredity and variation, logical and biological. Proc. American Philos. Soc., 1908, 7 pp. (Read April 20, 1906).

The affinities of the pelagic tunicates, No.1: On a new Pyrosoma. Mem. National Acad. Sci., vol. 10, 1906, 5 pp. 2 pls.

Dipleurosoma a new genus of Pyrosoma. Johns Hopkins University Circulars, 1906, no. 5, pp. 98-99, 2 cuts.

Evolution. Article in the "Reference Hand book of the Medical Sciences," 1906, pp. 733-736.

\section{7}

Joseph Leidy. Pop. sci. Monthly, April, 1907.

Joseph Leidy. Pioneers of American Science. American Museum of Natural History, New York, April, 1907, pp. 23-25; also in Anatomical Record, No. 5, January 1, 1907.

On Turritopsis nutricula (McCrady). Proc. Boston Soc. Nat. Hist., vol. 33, no. 8, 1907, pp. 429-460, pls. 30-35. (With Samuel Rittenhouse.) 
The homologies of the muscles of the subgenus Cyclosalpa. Johns Hopkins University Circulars, 195, March, 1907, pp. 1-2.

The foundations of zoölogy (2d. ed.) Macmillan Co., New York, 1907.

\section{8}

Biographical memoir of Alpheus Hyatt. Biographical Memoirs, National Acad. Sci., vol. 6, 1908.

The origin of the lung of Ampullaria. Carnegie Institution of Washington, Pub. 102, 1908, .pp. 95-104, pls. 1-7. (With Bartgis McGlone.)

The pelagic Tunicata of the Gulf-Stream; Parts 2, 3, and 4: 'On Salpa floridana, the subgenus Cyclosalpa, and on Oikopleura tortugensis, sp. nov. Carnegie Institution of Washington, Pub. 102, pp. 73-94, pls. 1-8. (4 with Carl Kellner), The province of science Popular Science Monthly, 1998, pp. 268-271.

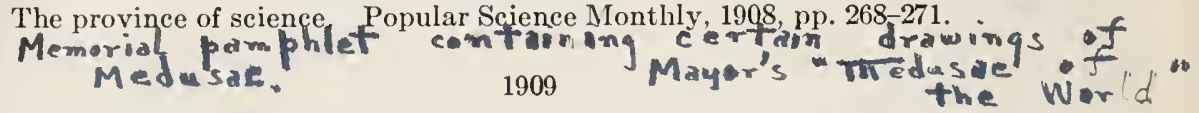

Are heredity and variation facts? Address at 7th International Zoölogical Congress, Boston, 1907 ; also reprinted as a memorial publication.

\section{UNPUBLISHED WORKS}

The axis of symmetry of the ovarian egg of the oyster. In press 1905, but still in MS., not published.

An extensive work on Salpa.

Lowell Lectures. 



